Prepared in cooperation with the New Hampshire Department of Environmental Services, Hazardous Waste and Remediation Bureau, and U.S. Environmental Protection Agency, Region 1, Waste Management Division

Results of a Monitoring Program of Continuous Water Levels and Physical Water Properties at the Operable Unit 1 Area of the Savage Municipal Well Superfund Site, Milford, New Hampshire, Water Years 2000-03

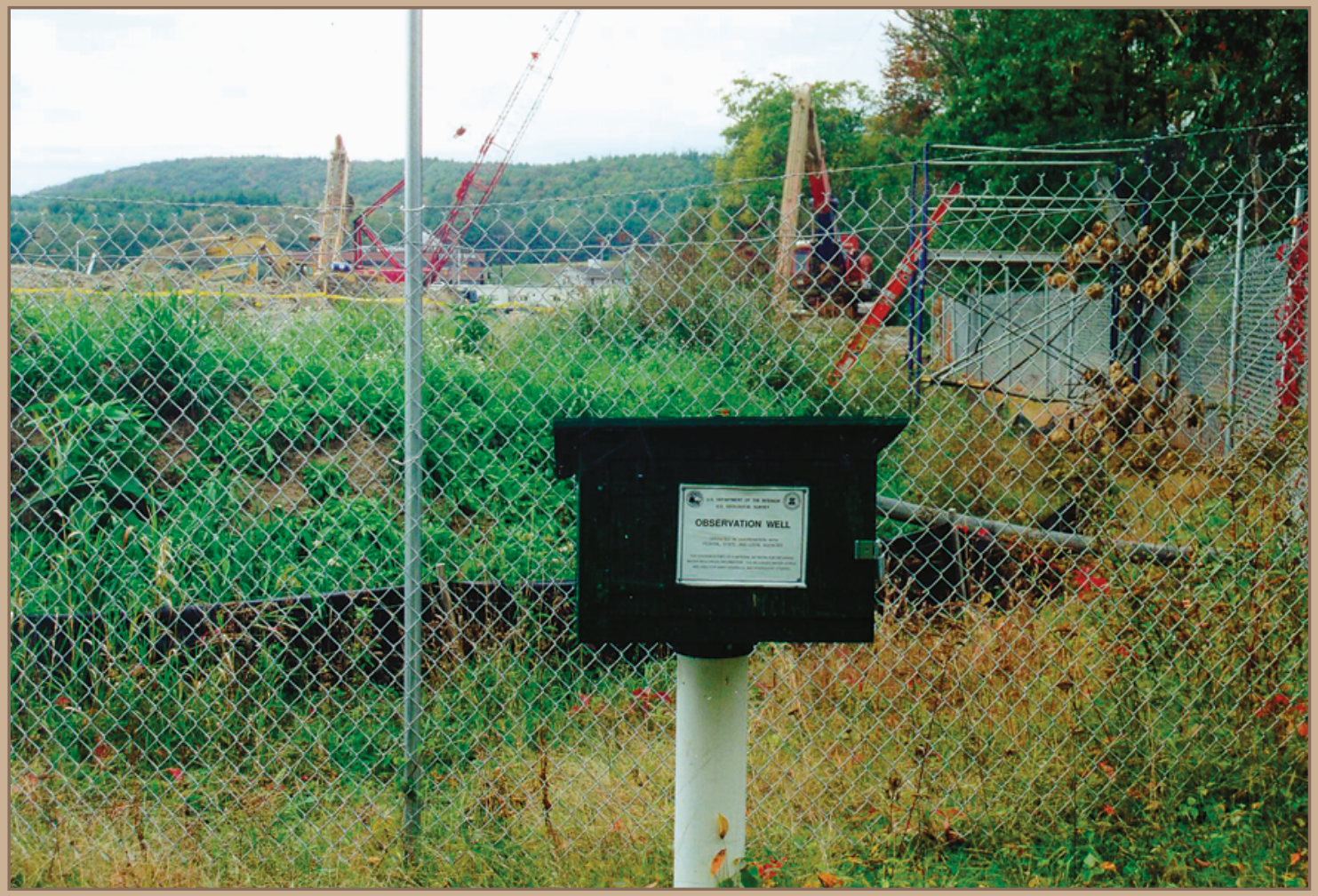

Open-File Report 2005-1303

U.S. Department of the Interior

U.S. Geological Survey 
Cover. Photograph shows a U.S. Geological Survey well shelter that contains continuous water-level recording equipment. The background shows construction work on the remedial system for Operable Unit 1 (OU1) of the Savage Municipal Well Superfund site in Milford, N.H. 


\section{Results of a Monitoring Program of Continuous Water Levels and Physical Water Properties at the Operable Unit 1 Area of the Savage Municipal Well Superfund Site, Milford, New Hampshire, Water Years 2000-03}

By Philip T. Harte

Prepared in cooperation with the

New Hampshire Department of Environmental Services,

Hazardous Waste and Remediation Bureau, and

U.S. Environmental Protection Agency, Region 1, Waste Management Division

Open-File Report 2005-1303 


\section{U.S. Department of the Interior \\ Gale A. Norton, Secretary \\ U.S. Geological Survey \\ P. Patrick Leahy, Acting Director}

U.S. Geological Survey, Reston, Virginia: 2005

For sale by U.S. Geological Survey, Information Services
Box 25286, Denver Federal Center
Denver, CO 80225
For more information about the USGS and its products:
Telephone: 1-888-ASK-USGS
World Wide Web: http://www.usgs.gov/

Any use of trade, product, or firm names in this publication is for descriptive purposes only and does not imply endorsement by the U.S. Government.

Although this report is in the public domain, permission must be secured from the individual copyright owners to reproduce any copyrighted materials contained within this report.

Suggested citation:

Harte, P.T., 2005, Results of a monitoring program of continuous water levels and physical water properties at the Operable Unit 1 area of the Savage Municipal Well Superfund site, Milford, New Hampshire, water years 2000-03: U.S. Geological Survey Open-File Report 2005-1303, 44 p. 


\section{Acknowledgments}

The study of the Savage Superfund site is a collaborative effort between Federal, State, and local governments, and private companies and individuals. The author wishes to express thanks for their cooperation and support to Richard Goehlert and Richard Willey of the U.S. Environmental Protection Agency, Region 1; and Thomas Andrews of the New Hampshire Department of Environmental Services. John Fritsch and Henry Staples of Veolia Water North AmericaNortheast, LLC. provided logistical support. 


\section{Contents}

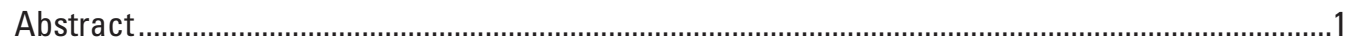

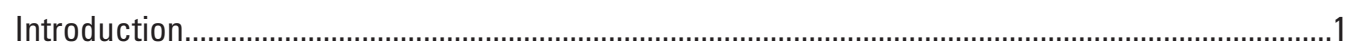

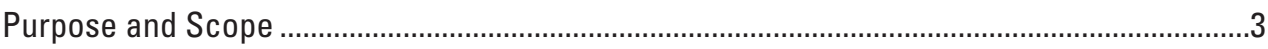

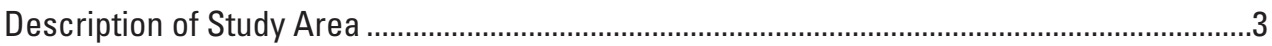

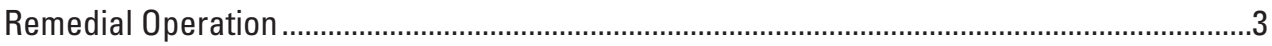

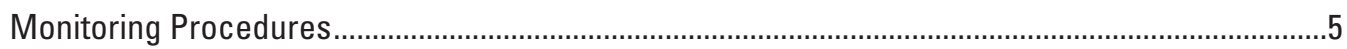

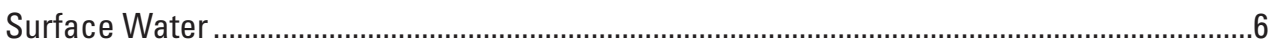

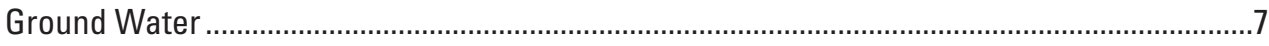

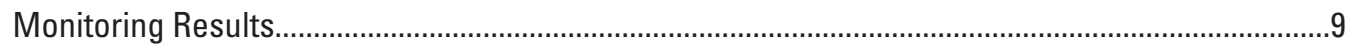

Hydrologic Monitoring and Remedial Operation ....................................................................

Water Levels and Physical Water Properties for Monitoring Locations..................................15

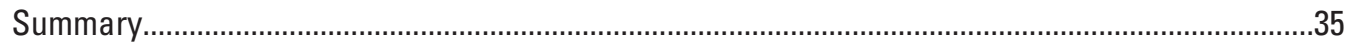

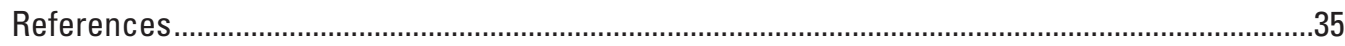

Appendix 1. Measuring point, well screen data, and geology for selected wells in the Operating Unit 1 area of the Savage Superfund site, Milford, N.H .......................................38

Appendix 2. Summary statistics for water level, specific conductance, and water temperature for automated monitoring wells, water years 2000-03, Milford, N.H. ...........41

Appendix 3. Periodic manual measurements of water levels for selected wells, water years 2000-03, Milford, N.H. (A) monitoring wells B95-8 and B95-9; (B) cluster monitoring wells PW-5R, PW-5D, and PW-5M inside the barrier wall; and (C) cluster monitoring wells PW-2D, PW-2R, PW-2M, and PW-2S outside the barrier wall ...............42

Appendix 4. Continuous (daily average) water levels for well MI-18, water years 19982003, Operable Unit 2 (OU2) area of the Savage Superfund site, Milford, N.H.

Appendix 5. Continuous (15-minute) water levels for wells PW-5R and PW-5D (inside barrier) and PW-2R and PW-2D (outside barrier), February 2002, Operable Unit 1 (OU1) area of the Savage Superfund site, Milford, N.H.

Appendix 6. Continuous (15-minute) water levels for wells PW-2R and PW-2D (outside barrier), November 2002, Operable Unit 1 (OU1) area of the Savage Superfund site, Milford, N.H.

\section{Figures}

1-2. Maps showing-

1. Location of the Milford-Souhegan glacial-drift aquifer, Savage well, and Operable Units 1 (OU1) and 2 (OU2) of the Savage Well Superfund site, Milford, N.H.

2. Remedial system of Operable Unit 1 (OU1) area (A) and continuous-monitoring sites (B) at the OU1 area of the Savage Superfund site, Milford, N.H..

3-6. Graphs showing ground-water levels for selected wells, daily precipitation amounts, and information on remedial operation, Operable Unit 1 (OU1) area of the Savage Superfund site, Milford, N.H., in water year-

3. 2000

4. 2001 


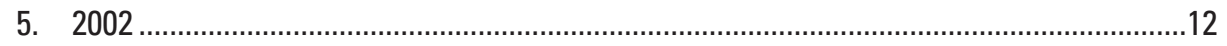

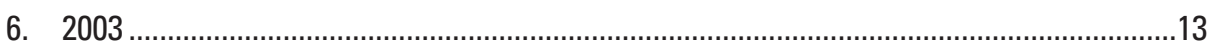

7-9. Graphs showing ground-water levels and physical water properties from monitoring well MI-18, Milford, N.H., in water year-

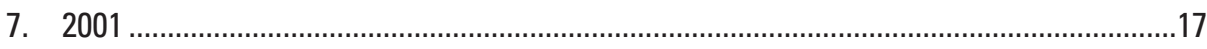

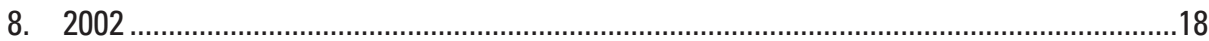



10-12. Graphs showing ground-water levels and physical water properties from monitoring well B95-9, Milford, N.H., in water year-

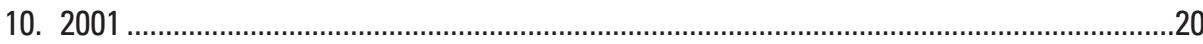

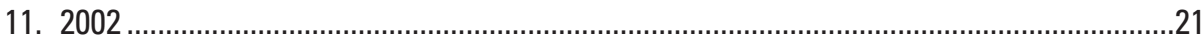

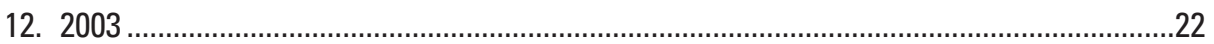

13-15. Graphs showing ground-water levels and physical water properties from monitoring wells PW-8M and PW-9M, Milford, N.H., in water year-

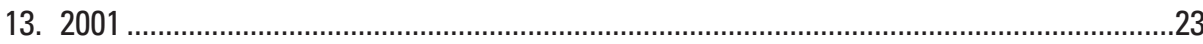

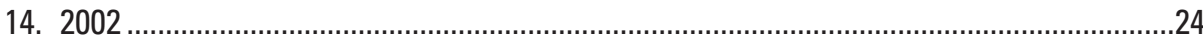

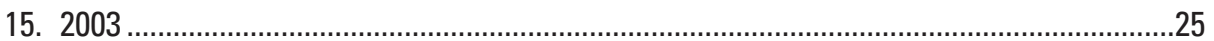

16-18. Graphs showing ground-water levels and physical water properties from monitoring wells PW-5R and PW-5D, Milford, N.H., in water year-





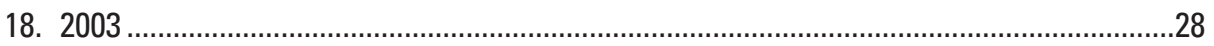

19-21. Graphs showing ground-water levels and physical water properties from monitoring wells PW-2R and PW-2D, Milford, N.H., in water year-

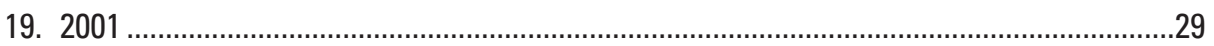

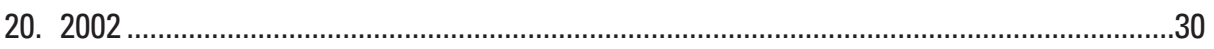

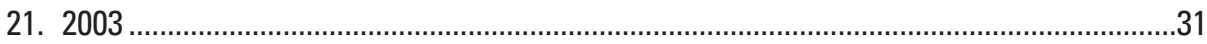

22-24. Graphs showing river stage, ground-water levels, and physical water properties from monitoring well P-2 and stream-gaging station P-2, Milford, N.H., in water year-

22. 2001

23. 2002

24. 2003

\section{Tables}

1. Remedial wells and operational rates for water years $2000-03,0 \mathrm{U} 1$ area of the Savage Superfund site, Milford, N.H.

2. Information on accuracy of water-level recording devices for continuously monitored sites, water years 2000-03, Operating Unit 1 area of the Savage

Superfund site, Milford, N.H.

3. Information on monitoring well and stream-gaging station construction and instrumentation for continuously monitored sites, Operating Unit 1 area of the Savage Superfund site, Milford, N.H.

4. Summary of daily water-level statistics for continuously monitored wells based on remedial-system operation status, OU1 area of the Savage Superfund site, water years 2002-03, Milford, N.H. 


\section{Conversion Factors, Vertical Datum, Water-Quality Units and Abbreviations}

\begin{tabular}{|c|c|c|}
\hline Multiply & By & To obtain \\
\hline \multicolumn{3}{|c|}{ Length } \\
\hline inch (in.) & 25.4 & millimeter $(\mathrm{mm})$ \\
\hline foot $(\mathrm{ft})$ & 0.3048 & meter $(\mathrm{m})$ \\
\hline mile (mi) & 1.609 & kilometer $(\mathrm{km})$ \\
\hline \multicolumn{3}{|c|}{ Area } \\
\hline square foot $\left(\mathrm{ft}^{2}\right)$ & 929.0 & square centimeter $\left(\mathrm{cm}^{2}\right)$ \\
\hline square mile $\left(\mathrm{mi}^{2}\right)$ & 2.590 & square kilometer $\left(\mathrm{km}^{2}\right)$ \\
\hline \multicolumn{3}{|c|}{ Flow rate } \\
\hline cubic foot per second $\left(\mathrm{ft}^{3} / \mathrm{s}\right)$ & 0.02832 & cubic meter per second $\left(\mathrm{m}^{3} / \mathrm{s}\right)$ \\
\hline million gallons per day (Mgal/d) & 0.04381 & cubic meter per second $\left(\mathrm{m}^{3} / \mathrm{s}\right)$ \\
\hline \multicolumn{3}{|c|}{ Hydraulic gradient } \\
\hline foot per mile (ft/mi) & 0.1894 & meter per kilometer $(\mathrm{m} / \mathrm{km})$ \\
\hline
\end{tabular}

Temperature in degrees Fahrenheit $\left({ }^{\circ} \mathrm{F}\right)$ may be converted to degrees Celsius $\left({ }^{\circ} \mathrm{C}\right)$ as follows:

$$
{ }^{\circ} \mathrm{C}=\left({ }^{\circ} \mathrm{F}-32\right) / 1.8
$$

Vertical coordinate information is referenced to the NGVD-29 (National Geodetic Vertical Datum of 1929).

The datum conversion from NGVD-29 to North American Vertical Datum-1988 (NAVD-88) is -0.68 feet at the study site.

Specific conductance is given in microsiemens per centimeter at 25 degrees Celsius $(\mu \mathrm{S} / \mathrm{cm}$ at $\left.25^{\circ} \mathrm{C}\right)$.

Concentrations of chemical constituents in water are given either in parts per million (ppm) or parts per billion (ppb).

$\begin{array}{ll}\text { UNITS OF MEASUREMENT } \\ \text { in/mo } & \text { inch per month } \\ \mathrm{yr} & \text { year }\end{array}$

ABBREVIATIONS AND EXPLANATIONS OF TERMS USED IN THIS REPORT

cis-1,2-DCE cis-1,2-dichloroethene

DNAPL'S Dense №n-

MSGD Milford-Souhegan glacial drift

OU1 Operable Unit 1 of the Savage Municipal Well Superfund Site

OU2 Operable Unit 2 of the Savage Municipal Well Superfund Site

PCE Tetrachloroethylene

PVC Polyvinyl chloride 
TCE Trichloroethylene

VOC Volatile organic compound

\section{WELL IDENTIFICATION, ABBREVIATIONS, AND EXPLANATION}

Well names used in this report, including appendix 1, are typically designated based on previous studies. In some cases, well names are designated after the owner's name.

Prefix for remedial wells

EW

Exterior barrier wall extraction well

IW

Interior barrier wall extraction well

RW

Recharge wells

SP

Air sparge well (used for remedial technology that reduces concentrations of volatile contaminants adsorbed to soils and dissolved in ground water in the saturated zone; involves the injection of air into the saturated zone)

SVE

Soil vapor extraction well (used for remedial technology that reduces concentrations of volatile contaminants adsorbed to soils in the unsaturated zone; involves the extraction of air from the unsaturated zone)

Prefix for observation wells

$\mathrm{P}$

Piezometer

PW, B, MI, and MW Monitoring wells

Suffix for observation wells

D or C

Deep cluster well

$\mathrm{M}$ or B

Medium cluster well

$\mathrm{R}$

Bedrock well

$\mathrm{S}$ or $\mathrm{A}$

Shallow cluster well

Lithology abbreviations

c

Coarse

f

Fine

$\mathrm{m}$

Medium

Wx

Weathered

Rock

Bedrock 


\title{
Results of a Monitoring Program of Continuous Water Levels and Physical Water Properties at the Operable Unit 1 Area of the Savage Municipal Well Superfund Site, Milford, New Hampshire, Water Years 2000-03
}

\author{
By Philip T. Harte
}

\section{Abstract}

The Milford-Souhegan glacial-drift (MSGD) aquifer, in south-central New Hampshire, is an important source of industrial, commercial, and domestic water. The MSGD aquifer was also an important source of drinking water for the town of Milford until it was found to contain high concentrations of volatile organic compounds (VOCs) in the Savage and Keyes municipal-supply wells in the early 1980s. A VOC plume was found to cover part of the southwestern half of the MSGD aquifer. In September 1984, the site was designated a Superfund site, called the Savage Municipal Well Superfund site. The primary source area of contaminants was a former tool manufacturing facility (called the OK Tool facility, and now called the Operable Unit 1 (OU1) area) that disposed of solvents at the surface and in the subsurface. The facility was closed in 1987 and removed in 1998. A low-permeability containment barrier wall was constructed and installed in the overburden (MSGD aquifer) in 1998 to encapsulate the highest concentrations of VOCs, and a pump-and-treat remediation facility was also added. Remedial operations of extraction and injection wells started in May 1999.

A network of water-level monitoring sites was implemented in water year 2000 (October 1, 1999, through September 30, 2000) in the OU1 area to help assess the effectiveness of remedial operations to mitigate the VOC plume, and to evaluate the effect of the barrier wall and remedial operations on the hydraulic connections across the barrier and between the overburden and underlying bedrock Remedial extraction and injections wells inside and outside the barrier help isolate ground-water flow inside the barrier and the further spreading of VOCs. This report summarizes both continuous and selected periodic manual measurements of water level and physical water properties (specific conductance and water temperature) for 10 monitoring locations during water years 2000-03. Additional periodic manual measurements of water levels were made at four nearby monitoring wells. Water levels are referenced to periods of remedial extraction and injection operations.
Remedial extraction inside the barrier in the overburden causes water-level drawdowns in interior (inside the barrier) monitoring wells but also exterior (outside the barrier) monitoring wells. Drawdowns were observed in the following descending sequence at: interior overburden wells, interior underlying bedrock wells, exterior underlying bedrock wells, and exterior overburden wells.

\section{Introduction}

The Milford-Souhegan glacial-drift (MSGD) aquifer, in south-central New Hampshire (fig. 1), is an important source of industrial, commercial, and domestic water. The MSGD was also an important source of drinking water for the town of Milford until high concentrations (greater than 1,000 ppb; New Hampshire Water Supply and Pollution Control (NHWSPC) Division, 1985) of volatile organic compounds (VOCs) were detected in the Savage (fig. 1) and Keyes municipal-supply wells in the early 1980s. A VOC plume (fig. 1) was discovered to cover part of the southwestern part of the MSGD aquifer (NHWSPC Division, 1985). In September 1984, the site was designated a Superfund site, called the Savage Municipal Well Superfund site (HMM Associates, 1989), referred to in this report as the Savage Superfund site. The primary source area of contaminants was a former tool manufacturing facility (called the OK Tool facility) that disposed of solvents at the surface and in the subsurface through a floor drain in the facility and a leachfield. The Savage Superfund site is logistically divided into two operable units. Operable Unit 1 (OU1) covers the former OK Tool facility and Operable Unit 2 (OU2) covers the extended plume area (fig. 1). The VOC plume is composed primarily of tetrachloroethylene (PCE).

Although the tool facility was closed in 1987 and demolished in winter of 1998, lingering pockets of VOCs in the subsurface continued to contaminate ground water flowing through the OU1 area. In 1998, a low-permeability barrier 




Figure 1. Location of the Milford-Souhegan glacial-drift aquifer, Savage well, and Operable Units 1 (OU1) and 2 (OU2) of the Savage Well Superfund site, Milford, N.H. (Modified from Harte, 2004.) 
wall was constructed and installed in the overburden (MSGD aquifer) to encapsulate the highest concentrations of VOCs (fig. 2A) beneath, and immediately adjacent to, the former OK Tool facility. Extraction and injection wells were installed to remediate the contaminant plume through capture, treatment, and re-injection of waters. Active remedial pumping and treatment began in May 1999.

A network of automated monitoring sites was developed and implemented in 1994 as part of an earlier, 3-year pre-remedial study by the U.S. Geological Survey (USGS), in cooperation with the U.S. Environmental Protection Agency (USEPA), to study transient hydrologic conditions in the aquifer (Harte and others, 1997). In water year ${ }^{1} 1997$, a remedial study was done by the USGS, in cooperation with the New Hampshire Department of Environmental Services (NHDES) and the USEPA, to modify the hydrologic network for increased data resolution in the OU1 area and to evaluate changes in ground-water levels inside and outside the barrier wall (Brayton and Harte, 2001). The hydrologic monitoring network was modified once again in water year 2000 to better evaluate hydraulic connections across the barrier and between the overburden (MSGD aquifer) and bedrock. The data collected with the continuous-monitoring network were used to evaluate changes in ground-water flow that may affect contaminant transport of VOCs and to assess the effectiveness of remedial operations to mitigate the VOC plume in the OU1 area.

\section{Purpose and Scope}

The purpose of this report is to provide data on water levels and other physical water properties as monitored by the U.S. Geological Survey at the former OK Tool facility (OU1 area) for water years 2000-03 (October 1, 1999, through September 30, 2003). This report summarizes both continuous and selected periodic or manual measurements of water level and physical water properties (specific conductance and water temperature) for 10 monitoring sites. Continuous measurements of river stage were made at one stream-gaging station. Continuous measurements of ground-water levels were made at nine monitoring wells. Continuous data are presented as graphs, and statistical summaries of data are in tables. Periodic water-level measurements, made at four nearby monitoring wells, are also presented on graphs.

\section{Description of Study Area}

The VOC plume is primarily in the MSGD aquifer but also within the underlying bedrock. The MSGD aquifer is located in a 3.3- $\mathrm{mi}^{2}$ area of the Souhegan River Valley in the town of Milford, N.H. The aquifer is defined as the entire

\footnotetext{
${ }^{1}$ Water year is the 12-month period October 1st through September 30th. The water year is designated by the calendar year in which it ends and includes 9 of the 12 months. Thus, the year ending September 30, 2002, is called the "2002 water year".
}

sequence of unsaturated and saturated alluvium, glacial drift, and other unconsolidated deposits including the basal till above the bedrock surface (Harte and Mack, 1992). The saturated thickness of the aquifer generally ranges from 0 to $60 \mathrm{ft}$, but approaches $100 \mathrm{ft}$ in some locations. The aquifer is laterally bounded by till-covered bedrock uplands.

The Souhegan River Valley slopes gently at $12 \mathrm{ft} / \mathrm{mi}$, with land-surface elevations ranging from 230 to $280 \mathrm{ft}$. The valley is drained to the east by the Souhegan River and many small tributaries. The river-valley system is composed of unconsolidated sediments consisting of alluvium and glacial deposits (stratified drift and till).

Land use within the valley varies from primarily industrial in the southwestern part of the study area, agricultural in the central and northwestern parts, and residential and commercial elsewhere. The VOC-contaminant plume underlies a $0.5-\mathrm{mi}^{2}$ area (fig. 1) of primarily agricultural land. The plume is in the sand-and-gravel units of the MSGD aquifer, the underlying till, and the bedrock (Harte, 2004). The plume is composed primarily of tetrachloroethylene (PCE). Secondary VOCs include tricholoroethylene (TCE) and cis-1,2-dichloroethylene (cis-1,2-DCE); both compounds are present from about 0.1 to 0.001 of the concentration of PCE (Harte, 2004).

Major withdrawals of ground water are from two wells (FH-4 and FH-5, fig. 1) operated by the New Hampshire State Fish Hatchery. These wells withdraw in excess of $1 \mathrm{Mgal} / \mathrm{d}$ to sustain fish-hatchery production. Most water withdrawn from these wells is returned to local streams. An industrial withdrawal well (MI-88) was in operation until August 2002 (Richard Goehlert, Environmental Protection Agency, written commun., 2002) and withdrew about $0.25 \mathrm{Mgal} / \mathrm{d}$ (Harte and others, 1999).

The OU1 area is in the western part of the MSGD aquifer (fig. 1). The remediation site is approximately $64,000 \mathrm{ft}^{2}$ bounded to the northwest by the Souhegan River; an important source of recharge to the MSGD aquifer. Near the OU1 area, the river loses approximately $4.5 \mathrm{ft}^{3} / \mathrm{s}$ of water to the aquifer (Harte and others, 2001). The stratigraphy underlying the remedial site consists of sands and gravels interbedded with fine sands (Harte and others, 2001). The bedrock slopes to the east and overburden thickness ranges from $40 \mathrm{ft}$ to the west and more than $80 \mathrm{ft}$ to the east. A discontinuous till veneer overlies the bedrock.

\section{Remedial Operation}

The remedial system at OU1 includes a low permeability (bentonite slurry) barrier wall that encapsulates the highest concentrations of VOCs (fig. 2A) found at the site. The barrier wall was installed to penetrate the full thickness of the sandand-gravel units of the MSGD aquifer and, in some places, the basal glacial till. Therefore, the wall is designed to contain VOCs in the overburden. Extraction and injection wells (fig. 2A, appendix 1) were installed in the overburden to remediate the contaminant plume through capture, treatment, 


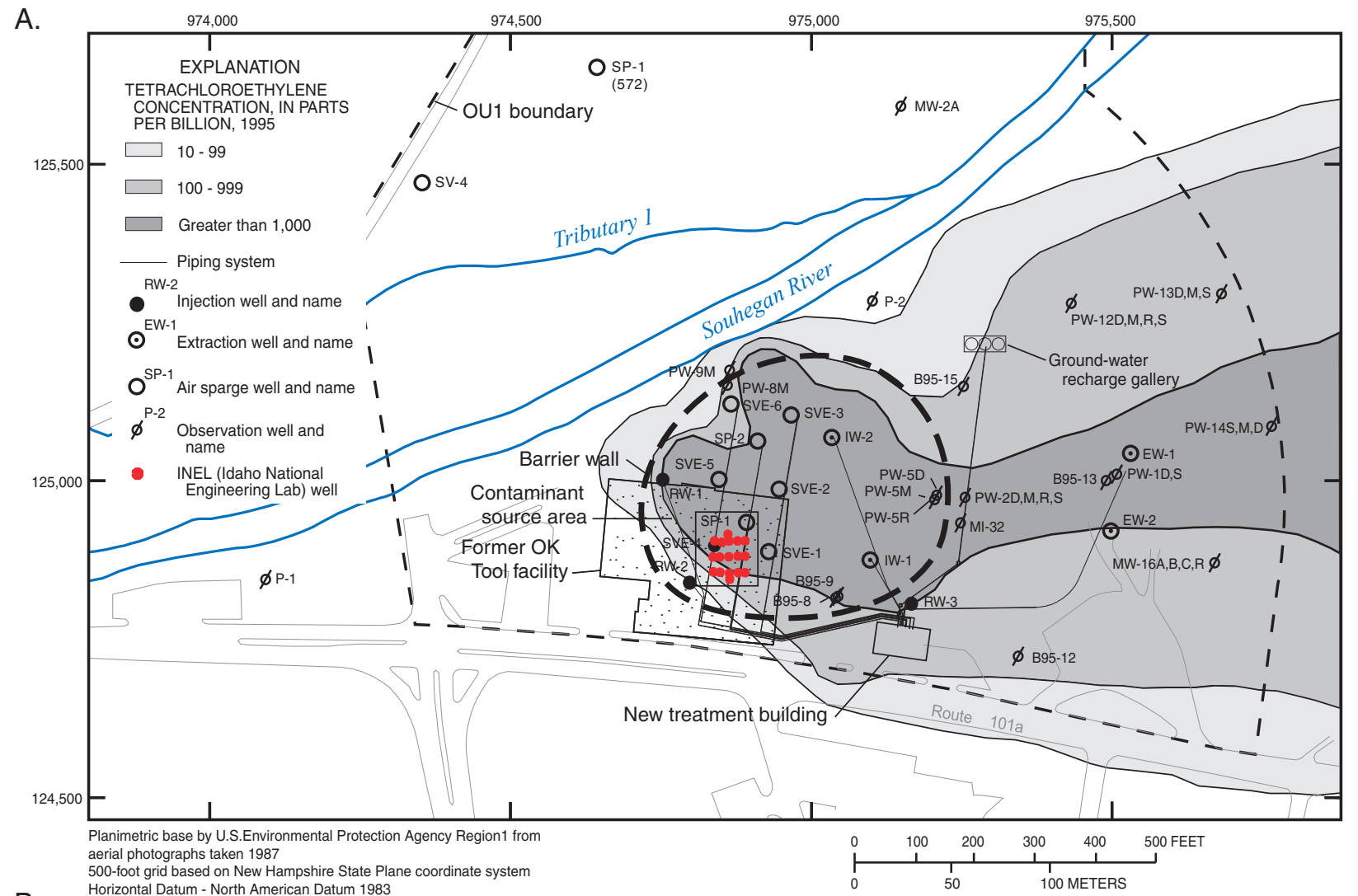

B.

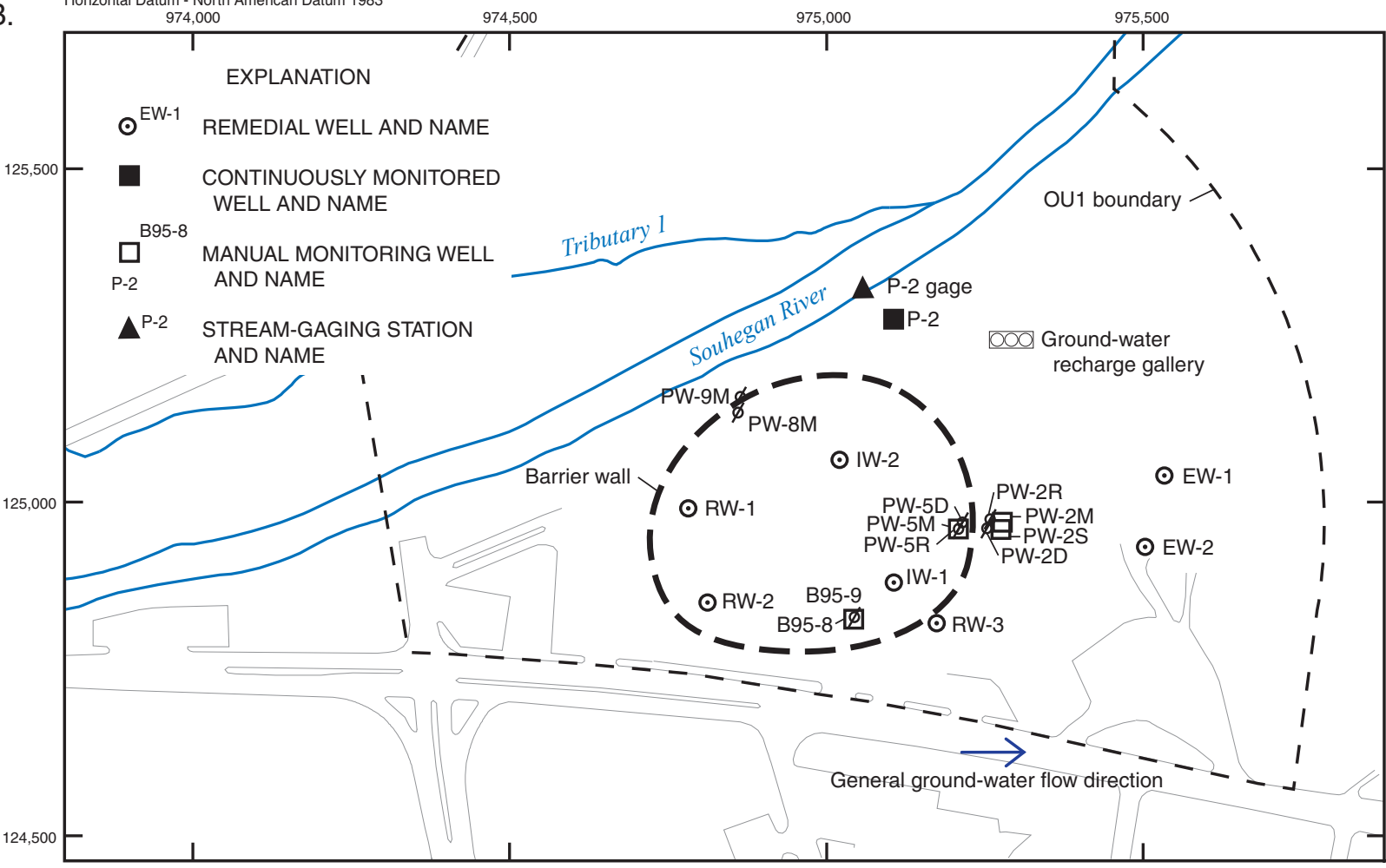

Figure 2. Remedial system of Operable Unit 1 (OU1) area (A) and continuous-monitoring sites (B) at the OU1 area of the Savage Superfund site, Milford, N.H. (Modified from Harte, 2004.) 
and re-injection of waters. Active remedial pumping began in March 1999. The following excerpt from Harte (2004) describes the remedial system:

The remedial extraction wells in OU1 help capture PCE where it is sent to a treatment facility (plant) for decontamination and injection back into the aquifer. Extraction wells include soil vapor extraction (SVE) wells and water wells. SVE wells are inside the barrier and have been sporadically used from 1998 to 2000. Ground-water extraction wells include the $I W-1$ and $I W-2$ (fig. $2 \mathrm{~A}$, this report) inside the barrier. These wells remediate PCE and maintain inward hydraulic gradients, which reduce outflow of PCE from the barrier area. Two groundwater extraction wells (EW-1 and EW-2, fig. $2 \mathrm{~A}$, this report) outside and downgradient of the barrier are used to capture the initial PCE occurring outside the barrier and to capture future transport of PCE from across the area of the barrier. Injection wells include two wells inside on the upgradient side of the barrier ( $R W-1$ and $R W-2$, fig. $2 \mathrm{~A}$, this report); these wells help prevent inflow of clean, uncontaminated waters from outside the barrier and to induce hydraulic gradients within the barrier. Another injection well ( $R W-3$, fig. $2 \mathrm{~A}$, this report) is outside on the downgradient side of the barrier. A recharge gallery, outside the wall on the northern flank of the plume (fig. 2A, this report), receives the bulk of the extracted water and injects water into the shallow (less than 20 feet) subsurface. Air sparging (SP) wells (SP-1 and SP-2, fig. 2A, this report) are inside the barrier and are used to inject air into the deep overburden to facilitate transfer of VOCs adhered onto soils into a vapor phase. SP wells were primarily inactive from 1998 to 2000. Soil vapor extraction wells (SVE 1-6, fig. 2A, this report) are inside the barrier and used to extract air from the shallow overburden and capture volatilized VOCs.

\footnotetext{
${ }^{2}$ All wells unless specifically noted in this report are ground-water wells.
}

The operation of remedial wells was changed during water years 2000-03 (table 1). Inside the barrier, extraction rates have increased at extraction wells IW-1 and IW-2, whereas injection rates have decreased at injection wells RW-1 and RW-2. The net effect is an increase in total water extracted inside the barrier. Outside the barrier, extraction rates have generally decreased at extraction wells EW-1 and EW-2 and injection rates have increased at injection well RW-3 and the ground-water recharge gallery.

Remedial-well operation is dependent on the capacity of the system to treat and dispose of treated water into the injection wells (RW-1,2,3) and recharge gallery. Most of the treated water is injected to the gallery. High water-level conditions, which occur in the spring during high streamflow in the Souhegan River, often prevent the injection and disposal of treated water back into the aquifer. Injection at the gallery creates a 4-6 ft water-table mound (U.S. Filter Engineering and Construction Inc., 2004). When water levels at P-2 well (located next to the Souhegan River) exceed $264 \mathrm{ft}$ above NGVD-29, the mound created by injection at the gallery rises nearer to the land surface (altitude of $269 \mathrm{ft}$ above NGVD-29) and decreases the capacity of the gallery to accept injected water. This increase in water level could temporarily shut off remedial operations in OU1 because the gallery is the primary injection location for the treated effluent.

\section{Monitoring Procedures}

Monitoring included the data collection of groundwater levels and physical water properties. Continuous measurements and records of river stage, ground-water level, specific conductance, and water temperature were made every 15 -minutes by electronic sensors wired to data loggers. To calibrate and validate the continuous measurements of these physical water properties, manual "check" measurements were also made on a monthly basis by using separate measurement devices. Manual measurements at additional sites were also used to supplement spatial coverage of continuousmeasurement sites.

Table 1. Remedial wells and operational rates for water years 2000-03, 0 U1 area of the Savage Superfund site, Milford, N.H.

[Well locations are shown on figure 2. All values are in gallons per minute (gal/min); rates represent mean rates while operating; * means combined mean rate. Data source from Veiola Water North America, LLC.]

\begin{tabular}{|c|c|c|c|c|c|c|c|c|}
\hline \multirow[b]{2}{*}{ Water year } & \multicolumn{3}{|c|}{ Inside barrier } & \multicolumn{4}{|c|}{ Outside barrier } & \multirow[b]{2}{*}{ Comments } \\
\hline & $\begin{array}{c}{ }^{*} \mathrm{RW}-1,2 \\
\text { (injection) }\end{array}$ & $\begin{array}{c}\text { IW-1 } \\
\text { (extraction) }\end{array}$ & $\begin{array}{c}\text { IW-2 } \\
\text { (extraction) }\end{array}$ & $\begin{array}{c}\text { RW-3 } \\
\text { (injection) }\end{array}$ & $\begin{array}{c}\text { Gallery } \\
\text { (injection) }\end{array}$ & $\begin{array}{c}\text { EW-1 } \\
\text { (extraction) }\end{array}$ & $\begin{array}{c}\text { EW-2 } \\
\text { (extraction) }\end{array}$ & \\
\hline 2000 & 0.0 & 13.5 & 15.4 & 0.0 & 58.9 & 14.5 & 15.5 & \\
\hline Early 2001 & .0 & 9.9 & 8.6 & .0 & 62.9 & 30.1 & 18.8 & \\
\hline Late 2001 & 3.1 & 14.9 & 15.5 & .0 & 76.2 & 30.1 & 18.8 & \\
\hline 2002 & .0 & 11.0 & 26.0 & .0 & 67.0 & 15.0 & 15.0 & Estimated rates. \\
\hline 2003 & .0 & 31.0 & 31.0 & 17.0 & 75.0 & 15.0 & 15.0 & Estimated rates. \\
\hline
\end{tabular}


River stage and ground-water levels are referenced to National Geodetic Vertical Datum of 1929 (NGVD-29). Measurement points were surveyed to nearby USGS benchmarks. The datum conversion from NGVD-29 to North American Vertical Datum-1988 (NAVD-88) is -0.68 feet at the site.

\section{Surface Water}

Continuous monitoring was prepared at one stream-gaging station (P-2 gage, fig. 2B). The instrumentation consisted of a 2-in.-diameter pipe directly connected to the river, with a pressure transducer installed at the base. Measurements were made every 15 minutes. The transducer recorded pressure, in pounds per square inch, above the water level; the pressure is a function of the height of the water column above the transducer. Some ice forms during the winter and river stages are affected by ice.

Continuous measurements from the pressure transducer were calibrated against periodic manual "check" measurements of stage at staff gages installed along the river bank. Using simple linear regression, a relation was established between pressure, measured in pounds per square inch (psi), and the corresponding "check" measurements of river stage. The regression was then used to convert the measured psi reading to stage. The performance of the pressure transducer was assessed based on the correlation (coefficient of determination, $\mathrm{R}^{2}$ ) between the concurrent manual stage measurements and pressure measurements and by the offset difference between the converted measurement and the manual measurement. Data from the river-stage pressure transducer had a $\mathrm{R}^{2}$ of 0.941 (table 2) with manual stage measurements. The average offset (mean difference, table 2) was calculated by summing all differences between stage values measured with the transducer and manual measurements, and dividing by the number of manual measurements. The mean difference was 0.0 (table 2). However, the absolute mean difference, which eliminates the canceling effects of positive and negative differences, was $0.15 \mathrm{ft}$

Physical water properties (specific conductance and temperature) of river water were manually measured on a monthly to bimonthly basis by use of separate independent sensors. In some cases, thick ice cover prevented the collection of specific conductance and temperature samples from the Souhegan River. Temperature measurements were made directly in the

Table 2. Information on accuracy of water-level recording devices for continuously monitored sites, water years 2000-03, 0perating Unit 1 area of the Savage Superfund site, Milford, N.H.

[Monitoring sites are shown on figure $2 ;<$, less than; Overburden means opened in Milford-Souhegan glacial-drift aquifer]

\begin{tabular}{|c|c|c|c|c|c|c|c|}
\hline \multirow[b]{2}{*}{$\begin{array}{c}\text { Well } \\
\text { number }\end{array}$} & \multirow[b]{2}{*}{$\begin{array}{l}\text { Monitoring } \\
\text { site }\end{array}$} & \multirow[b]{2}{*}{ Well type } & \multirow[b]{2}{*}{$\begin{array}{l}\text { Start of } \\
\text { record }\end{array}$} & \multirow[b]{2}{*}{$\begin{array}{l}\text { Type of } \\
\text { recording device }\end{array}$} & \multicolumn{2}{|c|}{ Accuracy of recorder } & \multirow[b]{2}{*}{ Comments } \\
\hline & & & & & $\begin{array}{c}\mathbf{R}^{2} \\
\text { (coefficient of } \\
\text { determination) } \\
\text { between automated } \\
\text { and manual } \\
\text { measurements }\end{array}$ & $\begin{array}{l}\text { Mean differ- } \\
\text { ence between } \\
\text { automated and } \\
\text { manual } \\
\text { measurements, } \\
\text { in feet }\end{array}$ & \\
\hline 535 & PW-2R & Bedrock & $01 / 23 / 01$ & Potentiometer & .736 & -.19 & $\begin{array}{l}\text { Float dislocated after } \\
\text { several sampling events. }\end{array}$ \\
\hline 534 & PW-2D & Overburden & $01 / 23 / 01$ & Pressure transducer & .999 & .00 & \\
\hline 541 & PW-5D & Overburden & $12 / 19 / 00$ & Pressure transducer & .998 & .00 & \\
\hline 29 & MI-18 & Overburden & $08 / 21 / 94$ & Potentiometer & .998 & .00 & \\
\hline 404 & B95-9 & Overburden & $07 / 21 / 97$ & Pressure transducer & .999 & $<.01$ & \\
\hline 550 & PW-9M & Overburden & $12 / 5 / 00$ & Pressure transducer & .997 & .00 & \\
\hline 549 & PW-8M & Overburden & $1 / 25 / 01$ & Pressure transducer & .999 & .00 & \\
\hline
\end{tabular}


river with a temperature sensor. Specific-conductance measurements were made with a specific-conductance meter on a bottled water sample upon return to the office.

The independent sensors for specific conductance and temperature were periodically checked to validate accuracy of measurements. The specific-conductance meter was calibrated to known standards (50 and $250 \mu \mathrm{S} / \mathrm{cm}$ ) that bracketed ranges of specific-conductance values observed in the field. Multiple temperature sensors were periodically compared to verify the reliability of the individual sensors. Reported values of specific conductance of river water were accurate to \pm 5 percent. Temperature data were accurate to within $\pm 1{ }^{\circ} \mathrm{C}$.

\section{Ground Water}

Nine monitoring wells were continuously measured for ground-water levels. These wells include B95-9, P-2, PW-8M and PW-9M, PW-2R and PW-2D, PW-5R and PW-5D, and ${ }^{3}$ MI-18 (figs. 1 and 2B). Monitoring wells P-2 and MI-18 were instrumented between May and September 1994. These wells provide information on background water levels because they are less affected by OU1 remedial operations than the other monitoring wells given their location. Monitoring well B95-9, inside the barrier, was instrumented in July 1997. The remaining monitoring wells were instrumented in water year 2001. Wells PW-8M and PW-9M are adjacent to the river and straddle the barrier wall to the north (fig. 2B). Wells from PW-5 and PW-2 clusters straddle the barrier to the east. Wellconstruction and monitoring-installation data are provided in table 3. All wells are 2 inches in diameter, except MI-18, which is a 3-ft-diameter, shallow dug well.

Continuous measurements of ground-water levels were made with stage potentiometers and attached floats and counterweights at PW-2R, PW-5R, and MI-18 (fig. 2). The potentiometer measured the depth of water level in feet below a known measurement point; water levels were automatically recorded at 15-minute intervals.

Discrepancies between continuous and "check" measurements were generally small (less than $0.05 \mathrm{ft}$ ). Corrections to potentiometers were made in the field if discrepancies exceeded $0.05 \mathrm{ft}$ by adjusting the potentiometer offset. When field corrections were made, continuous measurements were prorated linearly over the time in which the error occurred.

The average offset (mean difference, table 2) is an indicator of the reliability of the potentiometer and float-andweight system to accurately measure water levels. Continuous measurements from monitoring wells PW-5R and PW-2R had the largest discrepancies with "check" measurements (average offsets of -0.21 and $-0.19 \mathrm{ft}$, respectively). Discrepancies were primarily caused by inadvertent disturbance of the float-andweight system during routine sampling by field personnel. At MI-18, the average offset was zero.

Continuous measurements of ground-water levels were made every 15 minutes with downhole pressure transducers

\footnotetext{
${ }^{3}$ Also known as MOW-36 (Coakley and others, 1997).
}

at wells B95-9, P-2, PW-8M, PW-9M, PW-2D, and PW-5D (fig. 2). Continuous water levels were measured as pressure (psi) in height of column of water above the transducer. The accuracy of continuous pressure measurements was checked against concurrent manual measurements of water level that were made from a known measurement point. Linear-regression equations were used to (1) convert the pressure readings to water levels (in depth of water level below the measurement point), and (2) calibrate transducer measurements to manual "check" measurements. The accuracy of the pressure-transducer measurements was assessed based on the correlation $\left(\mathrm{R}^{2}\right)$ with the concurrent manual water-level measurements and the offset or difference between the continuous measurement and the manual measurement. All continuous measurements from monitoring wells showed a good correlation of pressure to water level, with $\mathrm{R}^{2}$ values greater than 0.997 (table 2). The average offset (mean difference, table 2) for wells with pressure transducers was essentially zero.

Specific conductance and temperature of ground waters were measured every 15 minutes at four wells: P-2, PW8M, PW-9M, and B95-9. These properties were measured by water-quality sensors, designed by the USGS Hydrologic Instrumentation Facility, and recorded by the same data loggers used to measure ground-water levels. Air temperature also was measured using thermistors connected to the data loggers. Specific-conductance and temperature data were measured manually on a monthly to bimonthly basis at well MI-18.

Continuous specific-conductance and temperature measurements were checked against concurrent "check" measurements of these same properties for all wells. Concurrent measurements were made in the field by extracting water samples using a peristaltic pump and measuring specific conductance and water temperature with separate meters. Wells were pumped after measuring the static water level and between 15-minute recordings of water level so as not to affect continuous-level measurements. Continuous values of specific conductance were not adjusted to match "check" measurements unless the difference was greater than 20 percent, in which case an adjustment procedure was applied, similar to that used for continuous water levels recorded by potentiometers. If manual measurements differed from continuous measurements by more than 20 percent for three consecutive "check" measurements, then the continuous specific-conductance sensors were removed, cleaned with soap, rinsed, and reinstalled to correct the problem.

Discrepancies between continuous and "check" measurements for water temperature typically ranged from 10 to 30 percent of the continuous values. Large discrepancies, however, were found between continuous and "check" measurements because the pumped water, during transit in the pump line from the well to the surface, is subject to thermal warming or cooling depending on the air temperature. Consequently, manual water-temperature measurements obtained by pumping were considered less reliable than the continuous down-hole water-temperature measurements and no adjustments were made to the water-temperature sensor or continuous water- 


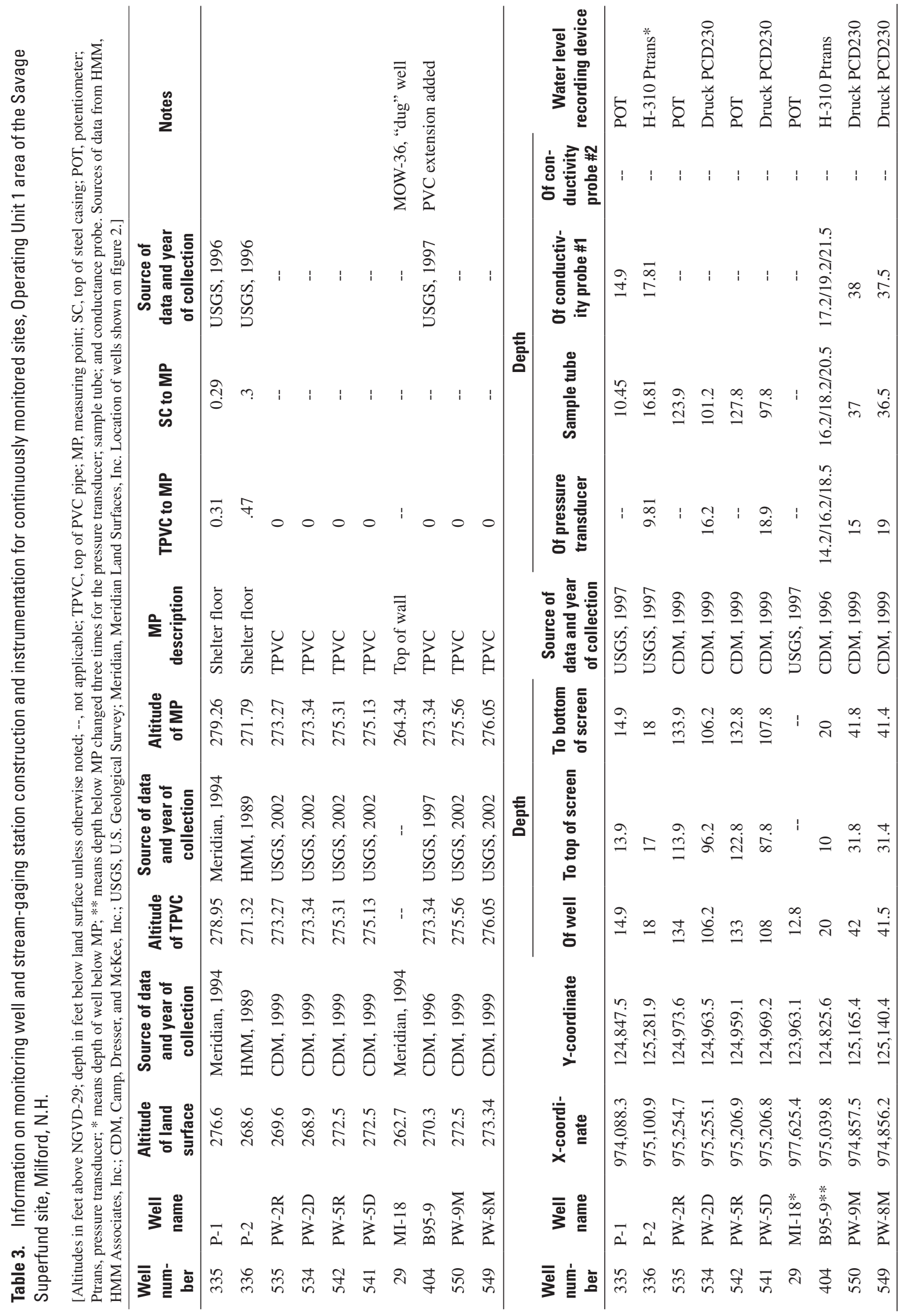


temperature data. The use of "check" temperature measurements to diagnose discrepancies in continuous temperatures was limited to large discrepancies (greater than 75 percent) when warming during pumping was less likely to be the cause of the discrepancy. Under these conditions, it was assumed and noted that the hardware malfunctioned causing an error in the data.

\section{Monitoring Results}

Monitoring results are provided in graphical and tabular format. Digital ${ }^{4}$ (continuous) data are available upon request from the USGS Water Science Center in Pembroke, N.H. In this report, emphasis is placed on summarizing waterlevel data during remedial operation of the extraction and injection system, as well as when the system is offline. For water years 2000-03, general remedial operation conditions are noted on selected graphs. Remedial operations are discontinuous and are determined by logistical, hydrologic, and remedial considerations.

Precipitation data also are included for reference to water-level fluctuations. Annual precipitation amounts for water years 2000-02 were below the long-term (1947-2003) mean of 45.33 in. as measured at the National Oceanic and Atmospheric Administration (NOAA) climatological station in Milford, N.H. (Station is outside the study area at latitude $42^{\circ} 48^{\prime} 36^{\prime \prime}$ and longitude $71^{\circ} 39^{\prime} 00^{\prime \prime}$; or State Planar Coordinates 988722.3 and 112977.6 and not shown on a figure). Water years 2000, 2001, and 2002 were 4.11 in., 5.28 in., and $10.4 \mathrm{in}$. below the long-term mean, respectively. Water year 2002 was in the low 6 percent of annual precipitation amounts. In contrast, water year 2003 was 1.58 in. above the long-term mean.

\section{Hydrologic Monitoring and Remedial Operation}

Daily average water levels, daily precipitation amounts (NOAA), and periods of remedial operation of interior (IW-1 and IW-2) and exterior (EW-1 and EW-2) extraction wells and the injection well at RW-3 (fig. 2) are provided for water years 2000-03 (figs. 3-6). Operational periods for the recharge gallery (fig. 2) are not shown because the gallery is always operating when any of the four extraction wells are operating. Water levels are shown in figure 3 for wells B95-9 (representing the interior barrier, fig. 2B), P-2 well (representing the exterior barrier areas by the river, fig. 2B), and MI-18 (representing the OU2 area, fig. 1). Additional water levels are shown in figures 4-6 for PW-5 (interior, fig. 2B) and PW-2 (exterior, fig. 2B) cluster wells, and PW-8M (interior, fig. 2B) and PW-9M (exterior, fig. 2B) wells. Remedial-operation periods for injection wells RW-1 and RW-2 are not shown in any

\footnotetext{
${ }^{4}$ Daily average values of water-level data are stored in the U.S. Geological Survey National Water Information System (NWIS) database.
}

figure because they were only in operation for brief periods during water year 2001 (table 3).

Water levels in well MI-18 do not respond to changes in remedial operation in OU1, whereas water levels from B95-9, PW-8M, PW-5 and PW-2 well clusters do respond. Remedial extraction causes water levels to decrease up to $3-5 \mathrm{ft}$ and when extraction is shut down, water levels increase by a similar amount. In contrast, water levels from wells P-2 (exterior by river) and PW-9M (exterior by river) generally do not respond to remedial operations.

Water-level response to daily precipitation during periods of static uniform or constant remedial operations show similar responses at most wells. Shallow well P-2 responds the most to precipitation, likely because of the proximity of the well to the river, with a corresponding increase in river stage. An analysis of P-2 water levels and river stage from data collected during water years 1994-96 indicated a strong correlation $\left(\mathrm{R}^{2}\right.$ of 0.92 ) between P-2 ground-water levels and adjacent river stage (Harte and others, 1997). Water levels in shallow well MI-18 respond the least to precipitation.

Remedial operations (injection and extraction) affect water levels, head potential, gradients, and ground-water flow directions across the barrier. When the remedial system is off, water levels at B95-9 (interior shallow well) exceed water levels at other interior wells (PW-8M, PW-5D, and PW-5R) and at exterior wells (PW-2R and PW-2D). In contrast, when the remedial system is on, water levels at interior wells (B95-9, PW-5D, and PW-8M) are the lowest and water levels at exterior wells (PW-2R and PW-2D) are the highest. Therefore, horizontal ground-water flow directions are reversed during remedial operation. Vertical ground-water flow directions are reversed inside the barrier during remedial operation and bedrock upflow results.

Statistical summaries (maximum, minimum, mean, and median) of continuous daily water levels are provided in various tables. Summaries of water levels, specific conductance, and water temperature are provided in appendix 2 for each site and water year. Summaries of daily average water-level statistics, during remediation off and on periods, for water years 2002-03 are provided in table 4.

The information in appendix 2 is useful to determine general water conditions for a given water year. Mean water levels for each water year at monitoring well MI-18 indicate that water levels were generally lowest during water year 2002 and highest for water year 2003. The cumulative precipitation amounts were 34.88 in. and 46.91 in. for water years 2002 and 2003 , respectively. Historically (50 years of record), water year 2002 ranks in the lower 10 percent, whereas water year 2003 ranks in the upper 45 percent of cumulative precipitation amounts.

Water-level differences between remedial on-off periods were greatest in water year 2003 (table 4), which also had the highest water levels for water years 2000-03 (appendix 2). Differences between remedial on-off periods are particularly evident in the daily minimum water-level statistics. The 


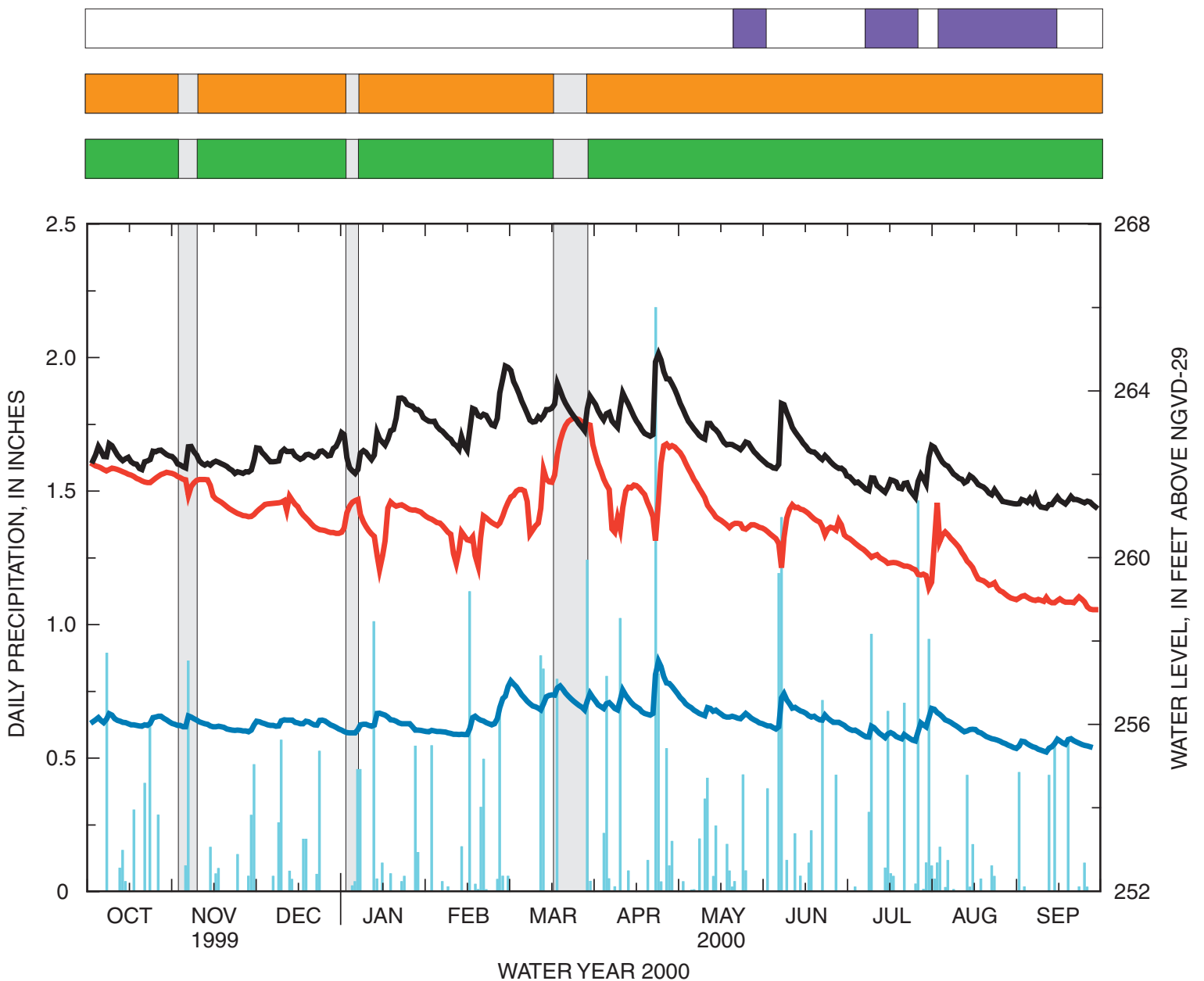

\section{EXPLANATION}

REMEDIAL OPERATION OF WELLS

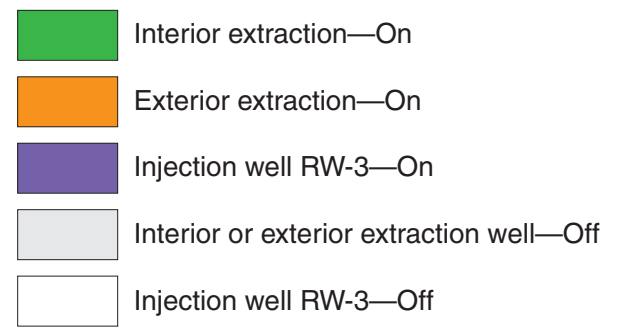

CLIMATE

Daily precipitation

WATER LEVELS IN MONITORING WELLS

B95-9

P-2 well

$\mathrm{Ml}-18$

Figure 3. Ground-water levels for selected wells, daily precipitation amounts, and information on remedial operation, water year 2000, Operable Unit 1 (OU1) area of the Savage Superfund site, Milford, N.H. (Location of wells shown on figures 1 or 2 .) 


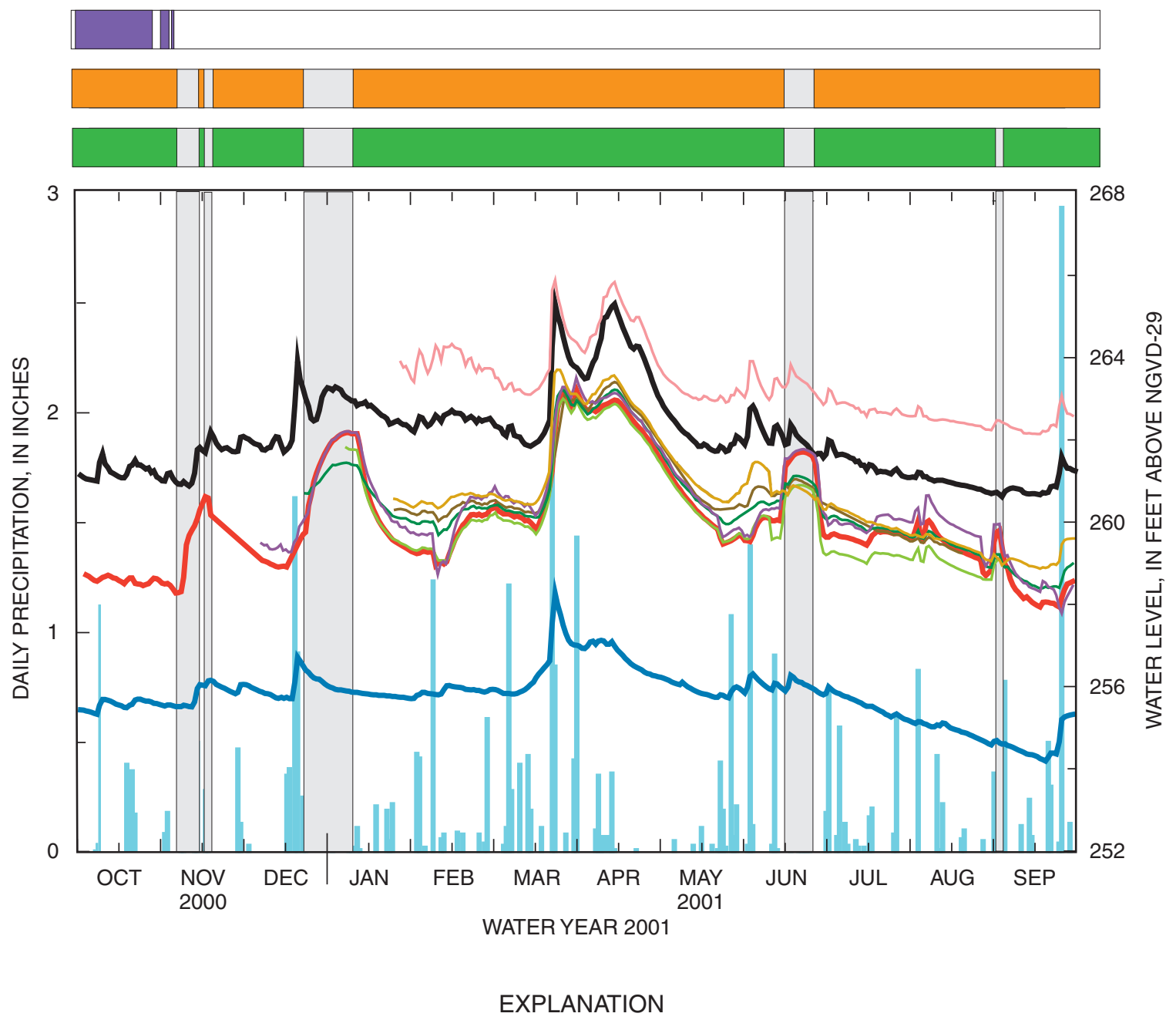

REMEDIAL OPERATION OF WELLS WATER LEVELS IN MONITORING WELLS

\begin{tabular}{|l|l}
\hline Interior extraction-On & B95-9 \\
\hline Exterior extraction-On & P-2 well \\
\hline Injection well RW-3-On & PW-18 \\
\hline Interior or exterior extraction well-Off & PW-2D \\
\hline Injection well RW-3-Off & PW-5R \\
\hline & PW-5D \\
\hline & PW-8M \\
\hline PW-9M
\end{tabular}

CLIMATE

Daily precipitation

Figure 4. Ground-water levels for selected wells, daily precipitation amounts, and information on remedial operation, water year 2001, Operable Unit 1 (OU1) area of the Savage Superfund site, Milford, N.H. (Location of wells shown on figures 1 or 2 .) 


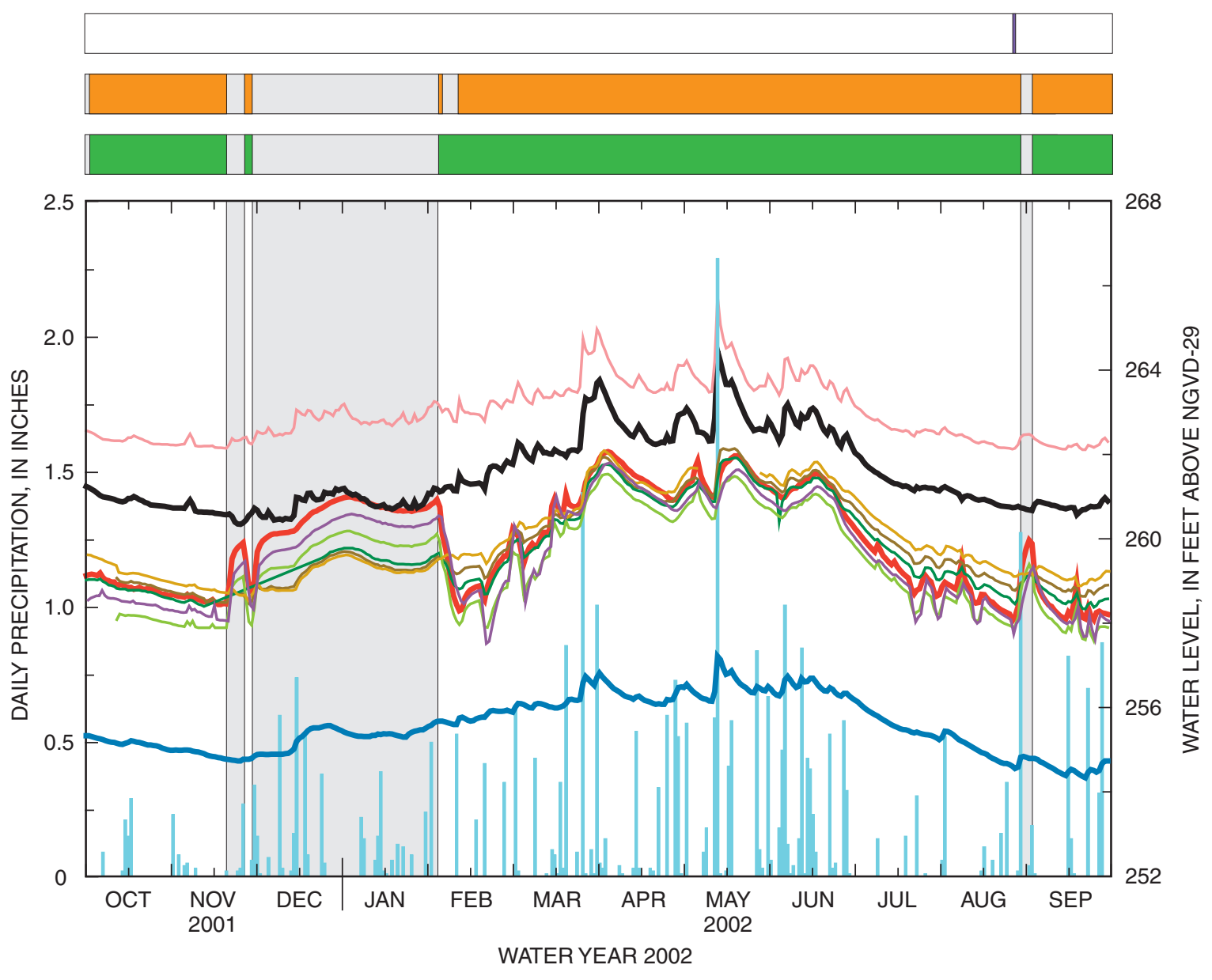

EXPLANATION

REMEDIAL OPERATION OF WELLS

WATER LEVELS IN MONITORING WELLS

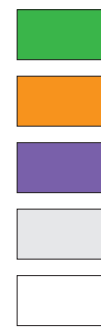

Interior extraction-On

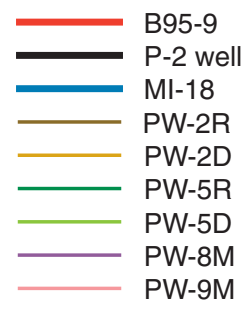

CLIMATE

Daily precipitation

Figure 5. Ground-water levels for selected wells, daily precipitation amounts, and information on remedial operation, water year 2002, Operable Unit 1 (OU1) area of the Savage Superfund site, Milford, N.H. (Location of wells shown on figures 1 or 2 .) 


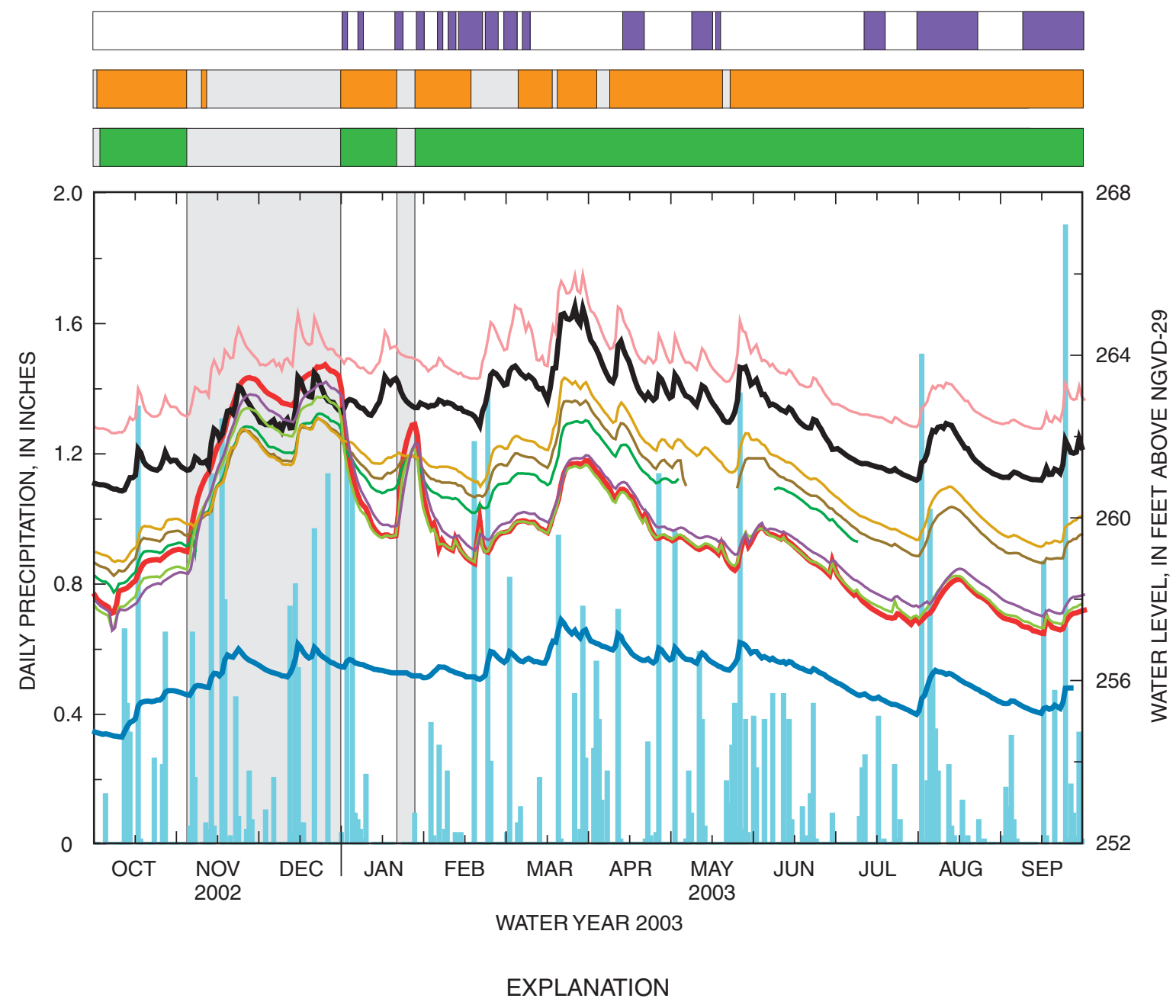

REMEDIAL OPERATION OF WELLS WATER LEVELS IN MONITORING WELLS

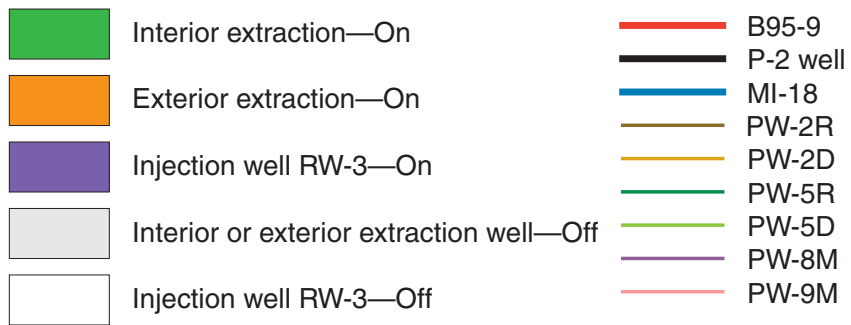

CLIMATE

Daily precipitation

Figure 6. Ground-water levels for selected wells, daily precipitation amounts, and information on remedial operation, water year 2003, Operable Unit 1 (OU1) area of the Savage Superfund site, Milford, N.H. (Location of wells shown on figures 1 or 2 . Gaps in lines of water levels indicate missing record.) 
Table 4. Summary of daily water-level statistics for continuously monitored wells based on remedial-system operation status, 0 U1 area of the Savage Superfund site, water years 2002-03, Milford, N.H.

[inside $=$ inside barrier; outside $=$ outside barrier; OU1 and OU2 = Operable Units 1 and 2; --, no data; *, difference in water levels from exterior extraction attributed to other factors besides remedial well in operation; Location of wells shown in figures 1 and 2B]

\begin{tabular}{|c|c|c|c|c|c|c|c|c|c|c|c|}
\hline \multirow[b]{3}{*}{$\begin{array}{c}\text { Well } \\
\text { and } \\
\text { location }\end{array}$} & \multirow[b]{3}{*}{ Statistic } & \multicolumn{5}{|c|}{ Water Year 2002} & \multicolumn{5}{|c|}{ Water Year 2003} \\
\hline & & \multicolumn{3}{|c|}{ Interior extraction } & \multicolumn{2}{|c|}{ Exterior extraction* } & \multicolumn{3}{|c|}{ Interior extraction } & \multicolumn{2}{|c|}{ Exterior extraction* } \\
\hline & & $\begin{array}{c}\text { Wells on } \\
\text { (feet } \\
\text { above } \\
\text { NGVD-29) }\end{array}$ & $\begin{array}{c}\text { Wells off } \\
\text { (feet } \\
\text { above } \\
\text { NGVD-29) }\end{array}$ & $\begin{array}{l}\text { Differ- } \\
\text { ence } \\
\text { (on } \\
\text { minus } \\
\text { off, in } \\
\text { feet) }\end{array}$ & $\begin{array}{l}\text { Wells } \\
\text { on }\end{array}$ & $\begin{array}{l}\text { Wells } \\
\text { off }\end{array}$ & $\begin{array}{c}\text { Wells on } \\
\text { (feet } \\
\text { above } \\
\text { NGVD-29) }\end{array}$ & $\begin{array}{c}\text { Wells off } \\
\text { (feet } \\
\text { above } \\
\text { NGVD-29) }\end{array}$ & $\begin{array}{l}\text { Differ- } \\
\text { ence* } \\
\text { (on } \\
\text { minus } \\
\text { off, in } \\
\text { feet) }\end{array}$ & $\begin{array}{l}\text { Wells } \\
\text { on }\end{array}$ & $\begin{array}{c}\text { Wells } \\
\text { off }\end{array}$ \\
\hline \multirow{3}{*}{$\begin{array}{l}\text { B95-9 } \\
\text { (inside) }\end{array}$} & Maximum & 261.95 & 260.87 & 1.08 & Not evaluated & -- & 263.06 & 262.19 & 0.87 & Not evaluated & -- \\
\hline & Mean & 259.76 & 260.36 & -.6 & Not evaluated & -- & 258.93 & 261.76 & -2.83 & Not evaluated & -- \\
\hline & Minimum & 257.92 & 258.76 & -.84 & Not evaluated & -- & 257.01 & 260.98 & -3.97 & Not evaluated & -- \\
\hline \multirow{3}{*}{$\begin{array}{l}\text { PW-8M } \\
\text { (inside) }\end{array}$} & Maximum & 261.65 & 260.44 & 1.21 & Not evaluated & -- & 262.85 & 261.73 & 1.12 & Not evaluated & -- \\
\hline & Mean & 259.36 & 259.94 & -.58 & Not evaluated & -- & 259.15 & 261.13 & -1.98 & Not evaluated & -- \\
\hline & Minimum & 257.4 & 258.33 & -.93 & Not evaluated & -- & 257.17 & 260.28 & -3.11 & Not evaluated & -- \\
\hline \multirow{3}{*}{$\begin{array}{l}\text { PW-9M } \\
\text { (outside) }\end{array}$} & Maximum & 265.63 & 263.14 & 2.49 & Not evaluated & -- & 265.9 & 263.92 & 1.98 & Not evaluated & -- \\
\hline & Mean & 262.91 & 262.67 & .24 & Not evaluated & -- & 263.34 & 263.86 & -.52 & Not evaluated & -- \\
\hline & Minimum & 261.99 & 262.11 & -.12 & Not evaluated & -- & 261.98 & 263.81 & -1.83 & Not evaluated & -- \\
\hline \multirow{3}{*}{$\begin{array}{l}\text { PW-5R } \\
\text { (inside) }\end{array}$} & Maximum & 261.8 & 259.65 & 2.15 & Not evaluated & -- & 262.29 & 261.42 & .87 & Not evaluated & -- \\
\hline & Mean & 259.72 & 259.4 & .32 & Not evaluated & -- & 260.41 & 261.29 & -.88 & Not evaluated & -- \\
\hline & Minimum & 258.2 & 258.75 & -.55 & Not evaluated & -- & 258.03 & 261.06 & -.03 & Not evaluated & -- \\
\hline \multirow{3}{*}{$\begin{array}{l}\text { PW-5D } \\
\text { (inside) }\end{array}$} & Maximum & 261.41 & 260.05 & 1.36 & Not evaluated & -- & 262.26 & 261.56 & .7 & Not evaluated & -- \\
\hline & Mean & 259.19 & 259.57 & -.38 & Not evaluated & -- & 258.9 & 261.24 & -2.34 & Not evaluated & -- \\
\hline & Minimum & 257.44 & 258.24 & -.8 & Not evaluated & -- & 257.15 & 260.65 & -3.5 & Not evaluated & -- \\
\hline \multirow{3}{*}{$\begin{array}{l}\text { PW-2R } \\
\text { (outside) }\end{array}$} & Maximum & 262.02 & 259.57 & 2.45 & 262.02 & 259.57 & 262.78 & 261.41 & 1.37 & 262.78 & 262.57 \\
\hline & Mean & 259.9 & 259.12 & .78 & 259.92 & 259.11 & 260.39 & 261.36 & -.97 & 260.29 & 261.43 \\
\hline & Minimum & 258.33 & 258.51 & -.18 & 258.33 & 258.51 & 258.45 & 261.28 & -2.83 & 258.45 & 261.12 \\
\hline \multirow{3}{*}{$\begin{array}{l}\text { PW-2D } \\
\text { (outside) }\end{array}$} & Maximum & 261.93 & 259.48 & 2.45 & 261.93 & 259.49 & 263.33 & 261.45 & 1.88 & 263.33 & 262.94 \\
\hline & Mean & 259.97 & 259.07 & .9 & 259.99 & 259.09 & 260.82 & 261.42 & -.6 & 260.73 & 261.77 \\
\hline & Minimum & 258.41 & 258.52 & -.11 & 258.41 & 258.52 & 258.86 & 261.4 & -2.54 & 258.84 & 261.4 \\
\hline \multirow{3}{*}{$\begin{array}{l}\text { MI-18 } \\
\text { (OU2) }\end{array}$} & Maximum & 257.07 & 255.53 & 1.54 & 257.07 & 255.53 & 257.35 & 256.75 & .6 & 257.35 & 256.83 \\
\hline & Mean & 255.52 & 255.09 & .43 & 255.51 & 255.12 & 255.95 & 256.19 & -.21 & 255.9 & 256.26 \\
\hline & Minimum & 254.18 & 254.49 & -.31 & 254.18 & 254.58 & 254.45 & 255.6 & -1.15 & 254.45 & 255.6 \\
\hline
\end{tabular}


difference in daily minimum water levels exceeded $3 \mathrm{ft}$ for water year 2003 but were generally less than $1 \mathrm{ft}$ for water year 2002.

Manual water-level measurements from continuously monitored wells and from selected wells nearby are shown graphically in appendix 3. Data include the "check" measurement from the continuous monitoring well and the manual measurement from the adjacent well(s). Results show the relative ranking of water levels are consistent and similar for B95-8 and B95-9 (B95-8 water levels exceeded B95-9 water levels) but changed for PW-5 and PW-2 cluster wells depending on remedial operation. These graphs can be compared to figures 3-6 to evaluate responses from remedial operation.

\section{Water Levels and Physical Water Properties for Monitoring Locations}

The results of data collection for each monitoring location are presented in graphical form in figures 7-24, with daily average values for water level, specific conductance (if available), and water temperature (if available) presented as a continuous data series unless otherwise indicated. These data span 3 water years (water years 2001-03) for each monitoring site. The monitoring period for most continuously monitored wells started in water year 2001 (table 2). The monitoring period for three wells (B95-9, P-2 well, and MI-18) started at an earlier date and include water year 2000 (fig. 3). To provide consistency of discussion, this section describes data only from water years 2001-03 when most monitoring took place.

The start of data records and any missing records are indicated directly on the graphs.

MI-18: This well is $1 \mathrm{mi}$ east of the OU1 area and serves as a background monitoring well (fig. 1). The well is $3 \mathrm{ft}$ in diameter, shallow (less than $20 \mathrm{ft}$ deep), and is used to measure water-table conditions. Water-level fluctuations are small, about $4 \mathrm{ft}$ annually (figs. 7-9). The minimum water level (254.04 ft) for the reporting period (water year 01-03) was in September 2001, preceding a storm associated with the remnants of Hurricane Gabrielle (National Oceanic and Atmospheric Administration, 2005). The maximum water level (258.13 ft) was in March 2001. Only specific-conductance and temperature measurements were made, and overall specificconductance variations are largest in 2001. A large range in water temperature $\left(10{ }^{\circ} \mathrm{C}\right)$ likely results from a large surface area of water in the well exposed to the air.

A long-term hydrograph (water years 1998-2003) from MI-18 is shown in appendix 4. Water levels from water years 2000, 2001, and 2003 generally exceed that from water year 2002 (a year of relatively low precipitation for the study period). Withdrawal operations were ceased at a nearby well (fig. 1, MI-88) in August 2002, which may contribute to the high water levels measured in water year 2003.

B95-9: This well is inside the barrier wall (fig. 2B) and screened in the shallow part of the overburden. Water levels at this well are affected by remedial operations (figs. 3-6) and fluctuate about $6 \mathrm{ft}$ (figs. 10-12). The maximum and minimum water levels for this period occurred in water year 2003 (fig. 12). Although water year 2003 had moderately high precipitation rates, which cause the daily maximum water levels to be high compared to other water years, increased extraction rates inside the barrier likely cause the low daily minimum water levels for the period. Remedial operation of SVE wells may also affect pressures measured by the transducer at this well. Specific-conductance values are fairly uniform in water years 2001-02 but variable in water year 2003. A large increase in specific conductance is coincident with the low water levels in water year 2003 (fig. 12). Water temperature fluctuates about $4{ }^{\circ} \mathrm{C}$ and follows an irregular pattern (not a regular sinusoidal pattern normally expected with water temperatures).

PW-8M and PW-9M: These wells straddle the barrier (PW-8M inside and PW-9M outside) to the north (fig. 2B) and are screened in the middle part of the overburden. The range of water-level fluctuation is about $6 \mathrm{ft}$ annually at PW-8M and $3 \mathrm{ft}$ at PW-9M (figs. 13-15). Water-level fluctuations are dissimilar because of the position of wells inside and outside of the barrier. Maximum water levels were measured in water year 2003 for both wells. Minimum water levels were measured in water year 2003 for PW-8M. Similar minimum water levels resulted in water years 2001-03 for PW-9M. Specific-conductance values are fairly uniform for PW-8M. A large rise in specific conductance was measured at PW-9M in May 2002, which corresponds to a precipitation event of 2.5 in. Annual variations in water temperature are large at PW$9 \mathrm{M}\left(6{ }^{\circ} \mathrm{C}\right)$ and minimum temperatures lag by about 3 months from air temperatures.

PW-5R and PW-5D: These wells are inside the barrier (fig. 2B) and screened in the bedrock (PW-5R) and lowermost overburden (PW-5D). Well PW-5D also partially penetrates the bedrock by $2 \mathrm{ft}$ and is designated as a hybrid well because the screen crosses multiple formations. Water-level fluctuations at PW-5D (6 ft) exceed fluctuations at PW-5R (4 ft) and levels vary based on remedial operation (figs. 3-6 and figs. 16-18). When remedial extraction wells inside the barrier are in operation, the water level at PW-5R is higher than at PW-5D; otherwise, when the extraction wells are off, the water level at PW-5D is higher than at PW-5R. Minimum and maximum water levels were measured in water year 2003.

Continuous specific conductance and temperature are unavailable for these wells. Manual measurements collected by NHDES show elevated specific-conductance values (above $500 \mu \mathrm{S} / \mathrm{cm}$ ) at PW-5R that are attributed to cement-grout contamination because $\mathrm{pH}$ of sampled water from $\mathrm{PW}-5 \mathrm{R}$ is abnormally high (exceeding 11 standard $\mathrm{pH}$ units) for a noncarbonate bedrock.

PW-2R and PW-2D: These wells are outside the barrier (fig. 2B) and screened in the bedrock (PW-2R) and lowermost overburden (PW-2D). Well PW-2D also partially penetrates the bedrock by $4 \mathrm{ft}$ and it is designated a hybrid well because the screen crosses multiple formations. Water-level fluctuations are similar between PW-2R and PW-2D (about $5 \mathrm{ft}$, 
figs. 19-21). Minimum and maximum water levels occurred in water year 2003. Specific-conductance data collected by NHDES show values (approximately $450 \mu \mathrm{S} / \mathrm{cm}$ ) at PW-2R exceed values at PW-2D by $200 \mu \mathrm{S} / \mathrm{cm}$.

Water-level drawdowns at the PW-2 and PW-5 well clusters (appendix 5) result because of operation of interior extraction wells IW-1 and IW-2 (fig. 2). At the PW-2 cluster, water-level response to interior extraction at $\mathrm{PW}-2 \mathrm{R}$ is much greater (by a factor of 2) than at PW-2D. This increase probably indicates the bedrock transmits water from inside and outside the barrier area. Water levels are shown in appendix 5 from 15-minute continuous measurements from February 4 to February 8, 2002, when little precipitation was recorded at Milford and no other extraction wells were in operation at OU1. In contrast, water levels at the PW-2 cluster showed little response to extraction at EW-1 and EW-2 when only those wells were in operation at OU1 in November 19-20, 2002 (appendix 6).

P-2 well and river: This well is between the barrier wall and the river (fig. 2B). The river staff gage is located about $30 \mathrm{ft}$ upstream. River stage affects ground-water gradients in OU1. Water levels in the P-2 well were highly affected by river stage (figs. 22-24). The river stage usually exceeds the ground-water level; however, during some periods, river stage can drop below the ground-water level. Maximum river stage and water levels at P-2 were measured in water year 2001 and minimums in water year 2002. Annual ground-water-level fluctuations were generally about $5 \mathrm{ft}$. Annual river-stage fluctuations can exceed $6 \mathrm{ft}$ (Brayton and Harte, 2001).

The variation in specific conductance of ground water from the P-2 well is similar to variation in the river. Watertemperature fluctuations range from $15{ }^{\circ} \mathrm{C}$ at well P-2 to $25^{\circ} \mathrm{C}$ at the $\mathrm{P}-2$ river gage. Well $\mathrm{P}-2$ has the largest water-temperature fluctuation of any well measured in the study area during water years 2001-03. Brayton and Harte (2001) found that lower water temperatures in the winter after barrier installation, rather than before installation, indicated an increase in recharge of river water to the MSGD aquifer at well P-2. The low minimum water temperatures for water year 2001-03 were similar to temperatures noted by Brayton and Harte (2001) for post-barrier installation. 

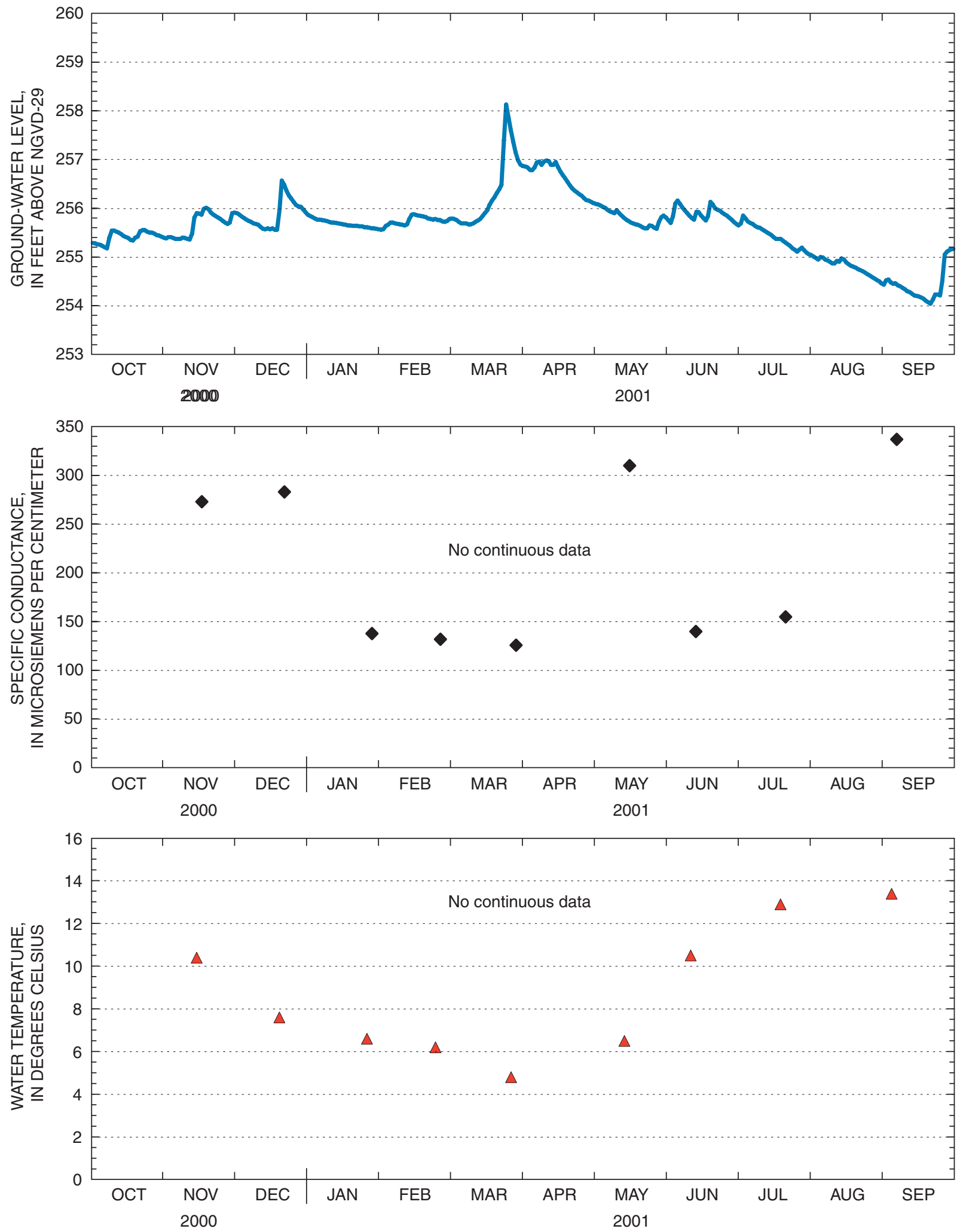

Figure 7. Ground-water levels and physical water properties from monitoring well MI-18, water year 2001, Milford, N.H. (Location of well shown on figure 1.) 

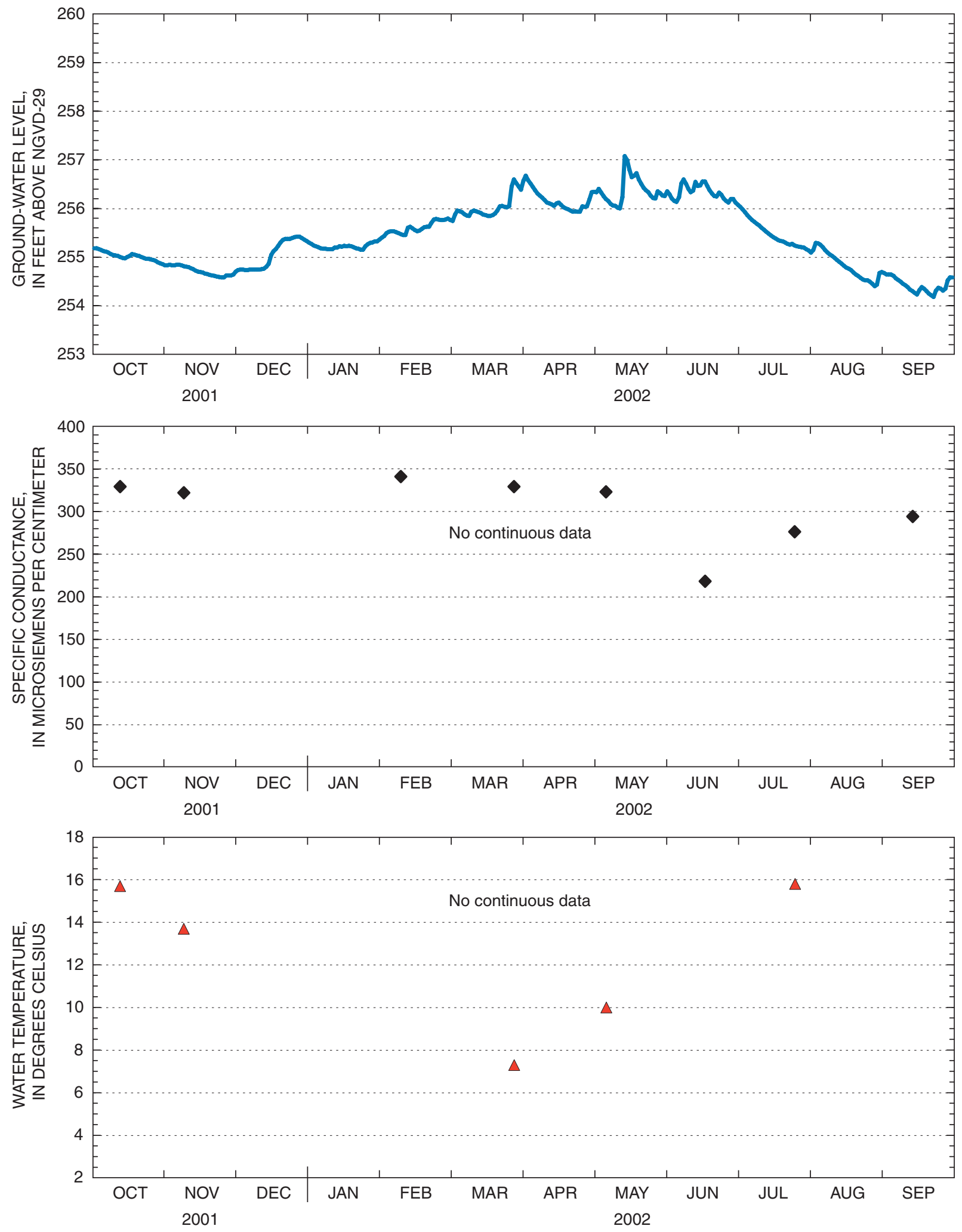

Figure 8. Ground-water levels and physical water properties from monitoring well MI-18, water year 2002, Milford, N.H. (Location of well shown on figure 1.) 

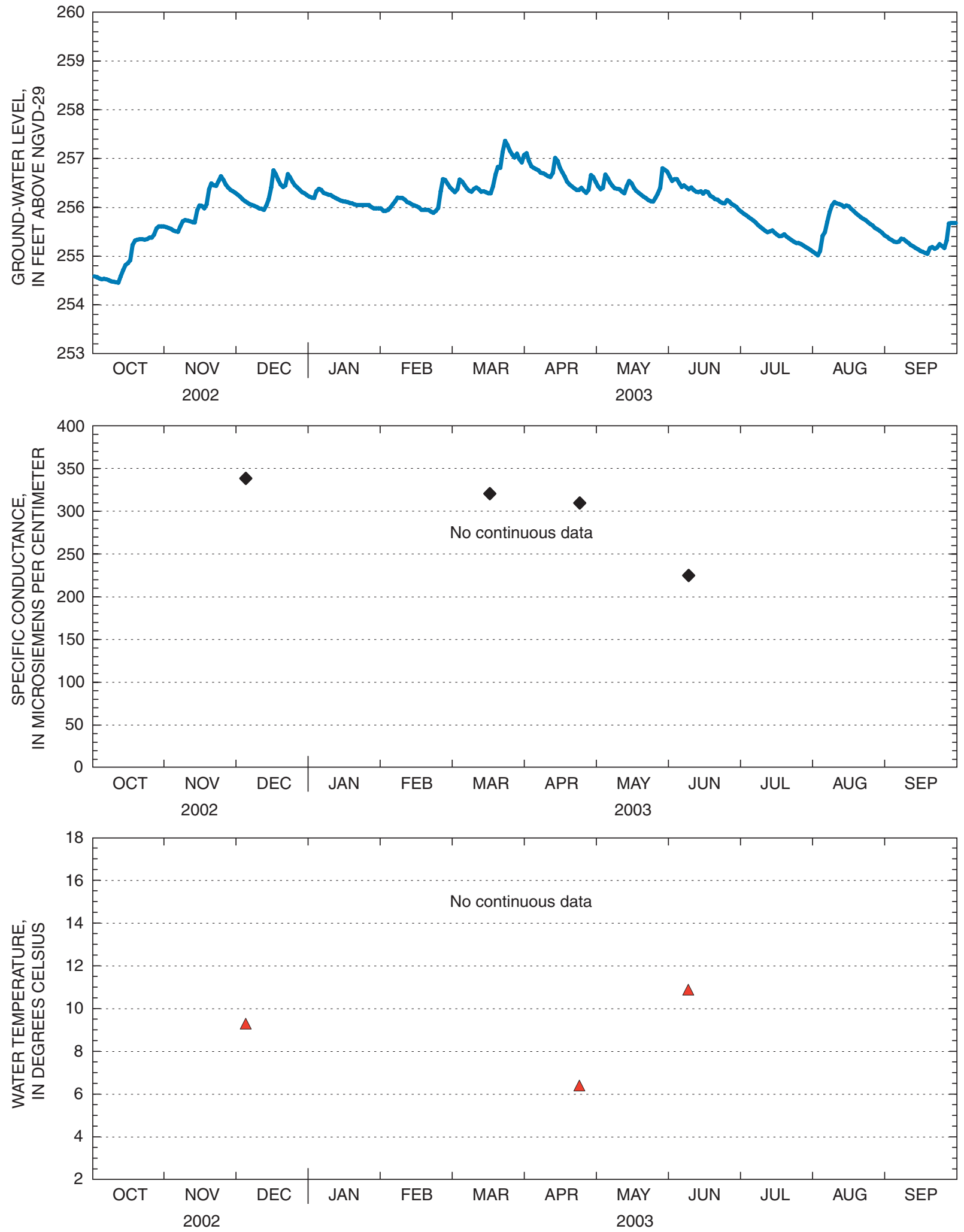

Figure 9. Ground-water levels and physical water properties from monitoring well MI-18, water year 2003, Milford, N.H. (Location of well shown on figure 1.) 

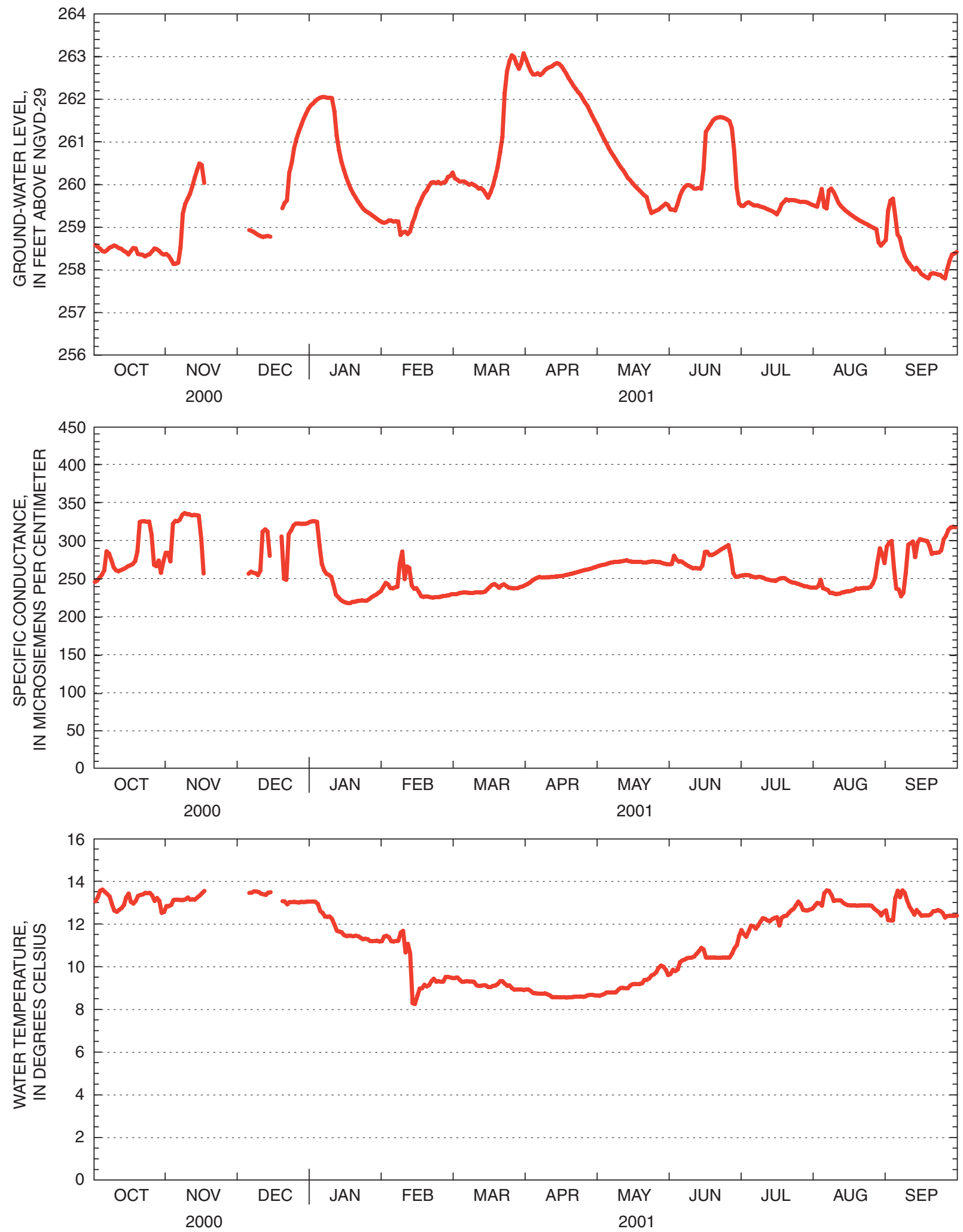

Figure 10. Ground-water levels and physical water properties from monitoring well B95-9, water year 2001, Milford, N.H. (Location of well shown on figure 2. Gaps indicate missing data.) 

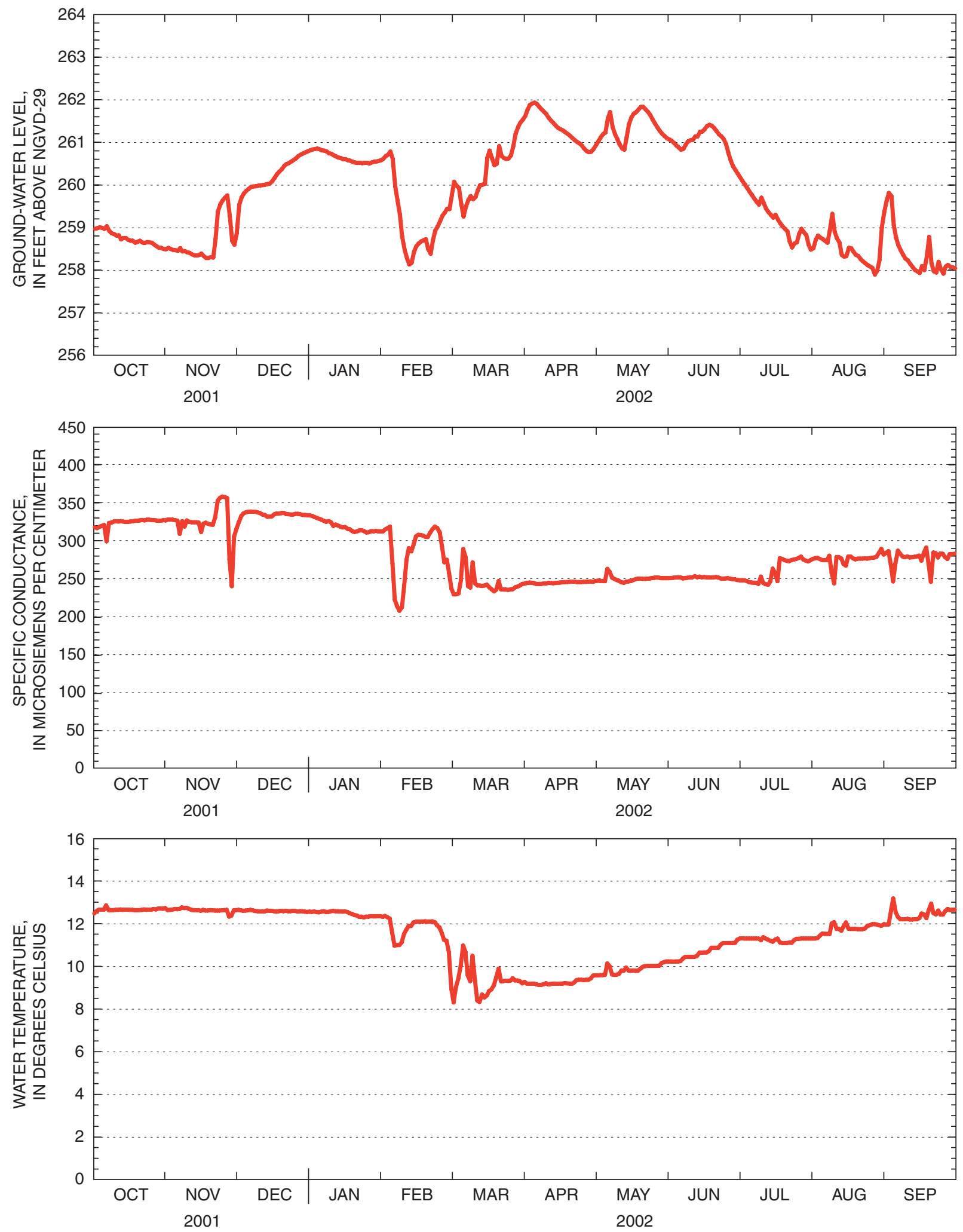

Figure 11. Ground-water levels and physical water properties from monitoring well B95-9, water year 2002, Milford, N.H (Location of well shown on figure 2.) 



Figure 12. Ground-water levels and physical water properties from monitoring well B95-9, water year 2003, Milford, N.H. (Location of well shown on figure 2.) 

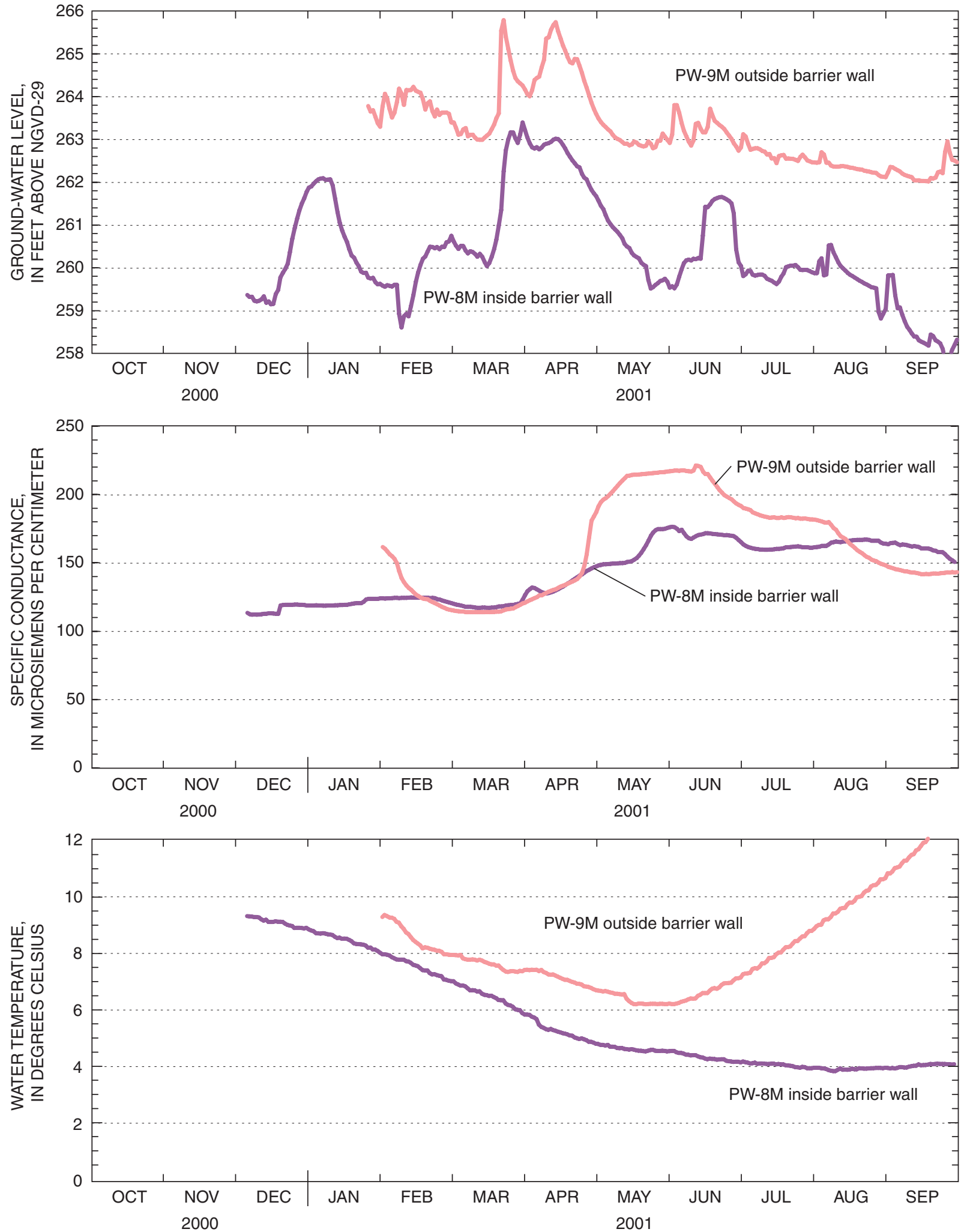

Figure 13. Ground-water levels and physical water properties from monitoring wells PW-8M and PW-9M, water year 2001, Milford, N.H. (Location of wells shown on figure 2. Gaps indicate missing data.) 

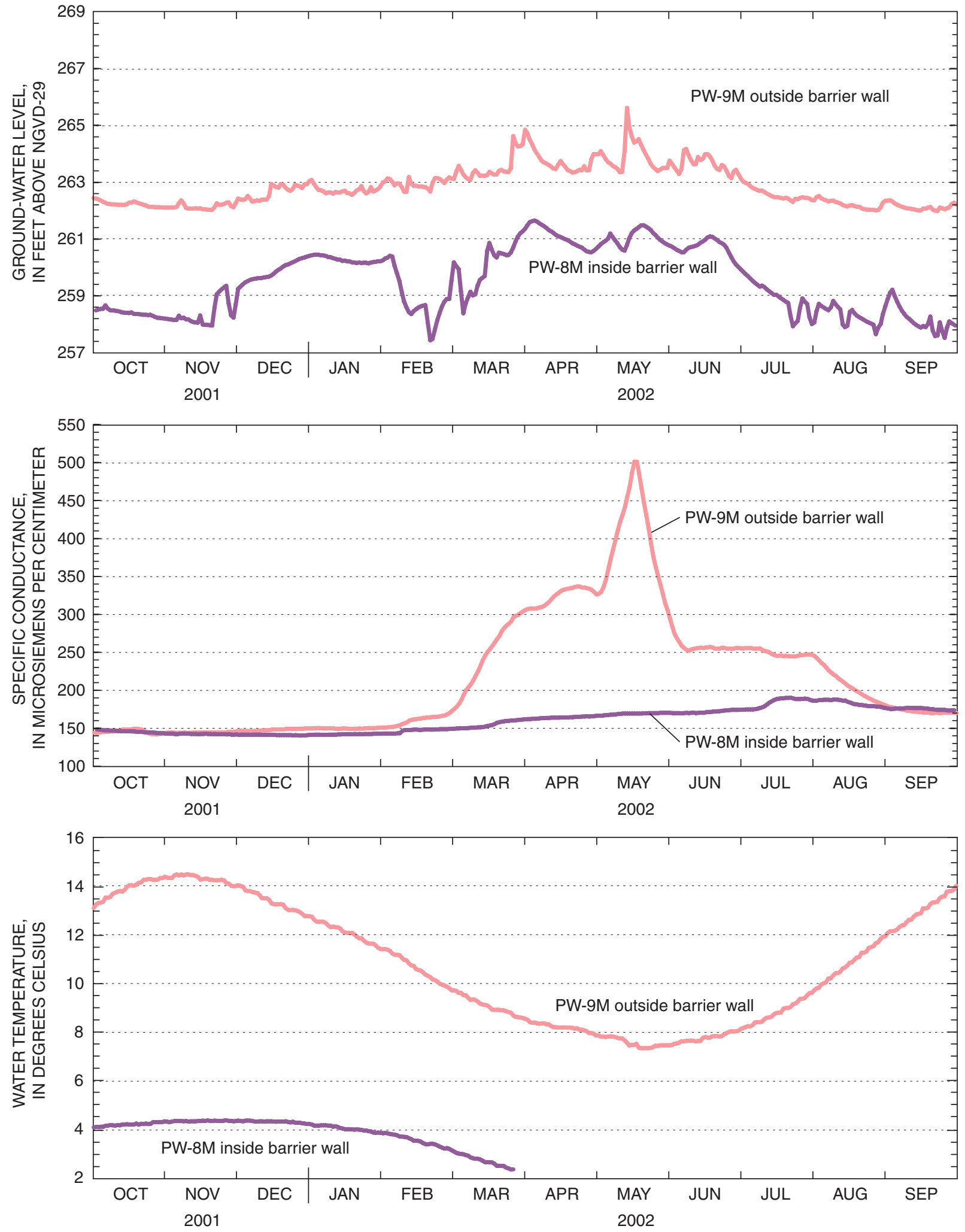

Figure 14. Ground-water levels and physical water properties from monitoring wells PW-8M and PW-9M, water year 2002, Milford, N.H. (Location of wells shown on figure 2. Gaps indicate missing data.) 

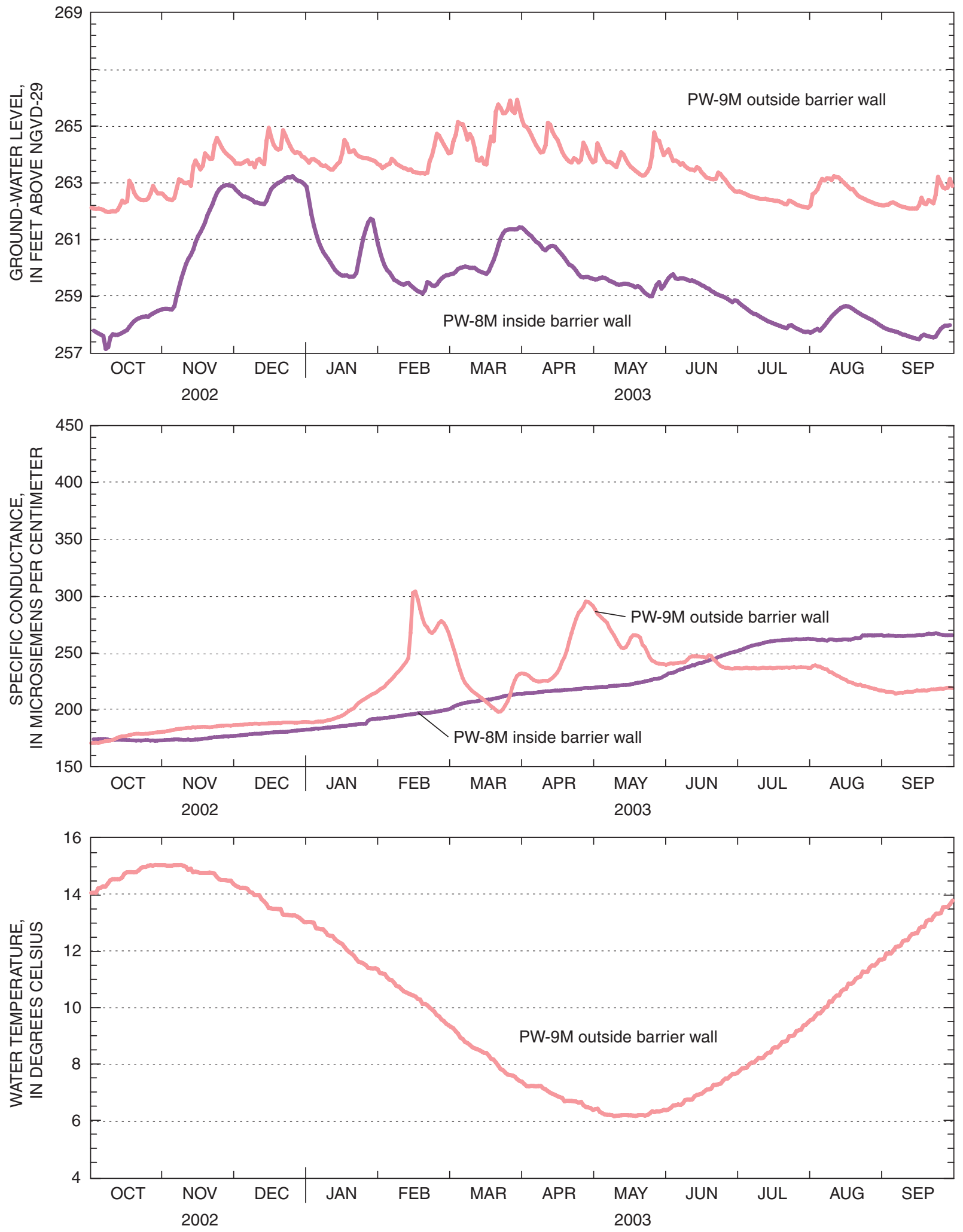

Figure 15. Ground-water levels and physical water properties from monitoring wells PW-8M and PW-9M, water year 2003, Milford, N.H. (Location of wells shown on figure 2. Temperature data for PW-8M unavailable.) 

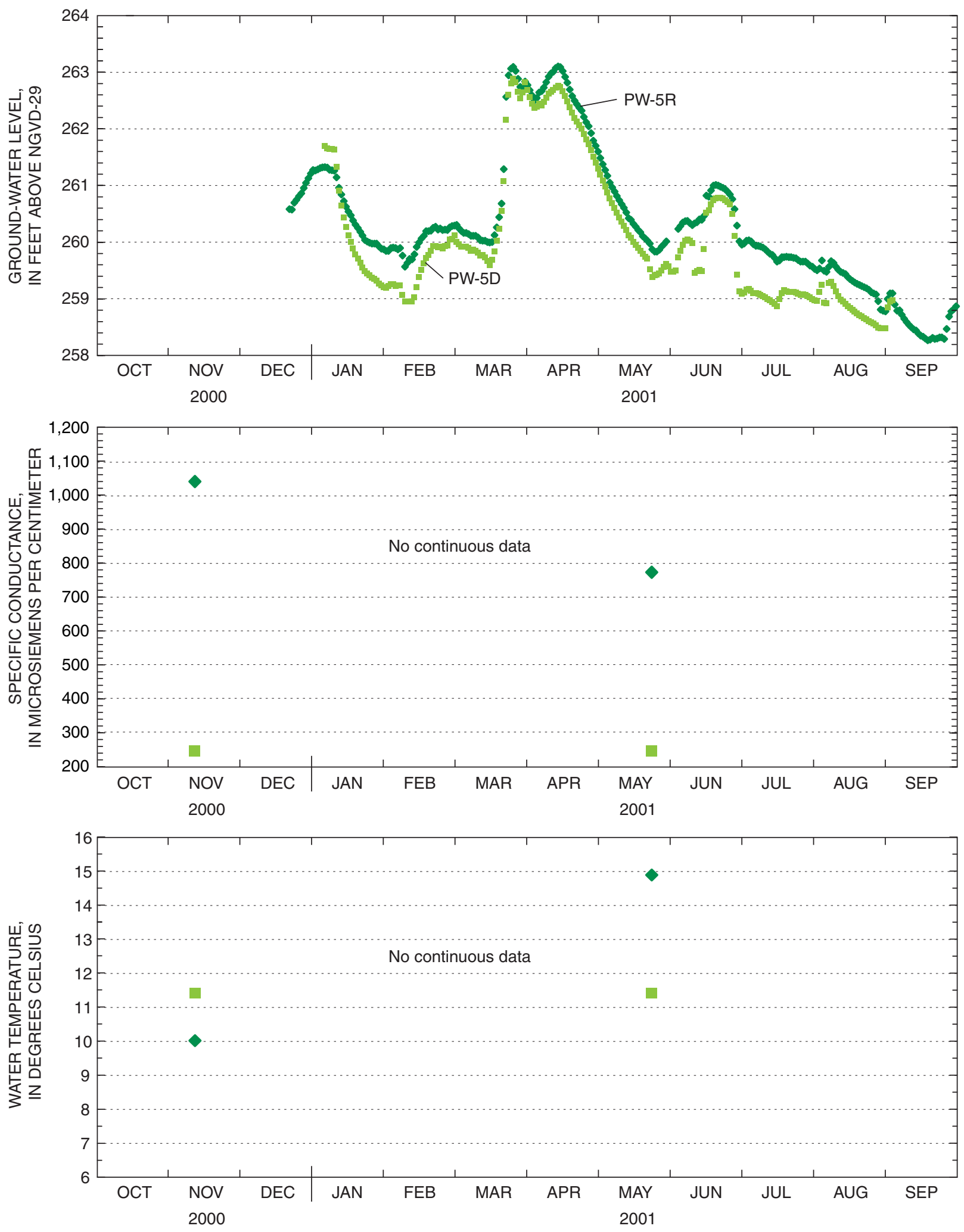

Figure 16. Ground-water levels and physical water properties from monitoring wells PW-5R and PW-5D, water year 2001, Milford, N.H. (Location of wells shown on figure 2. Gaps indicate missing data.) 

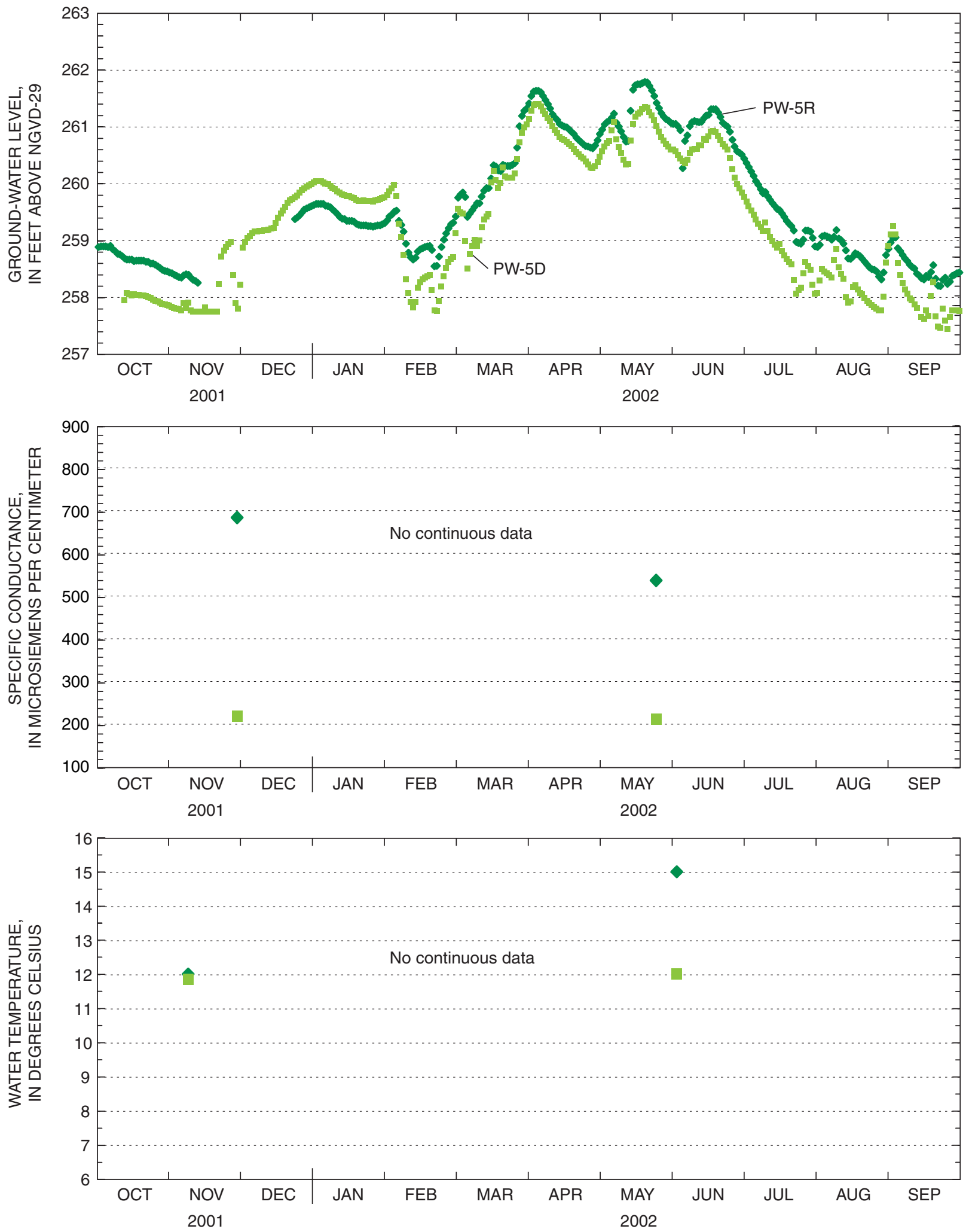

Figure 17. Ground-water levels and physical water properties from monitoring wells PW-5R and PW-5D, water year 2002, Milford, N.H. (Location of wells shown on figure 2. Gaps indicate missing data.) 



Figure 18. Ground-water levels and physical water properties from monitoring wells PW-5R and PW-5D, water year 2003, Milford, N.H. (Location of wells shown on figure 2. Gaps indicate missing data.) 

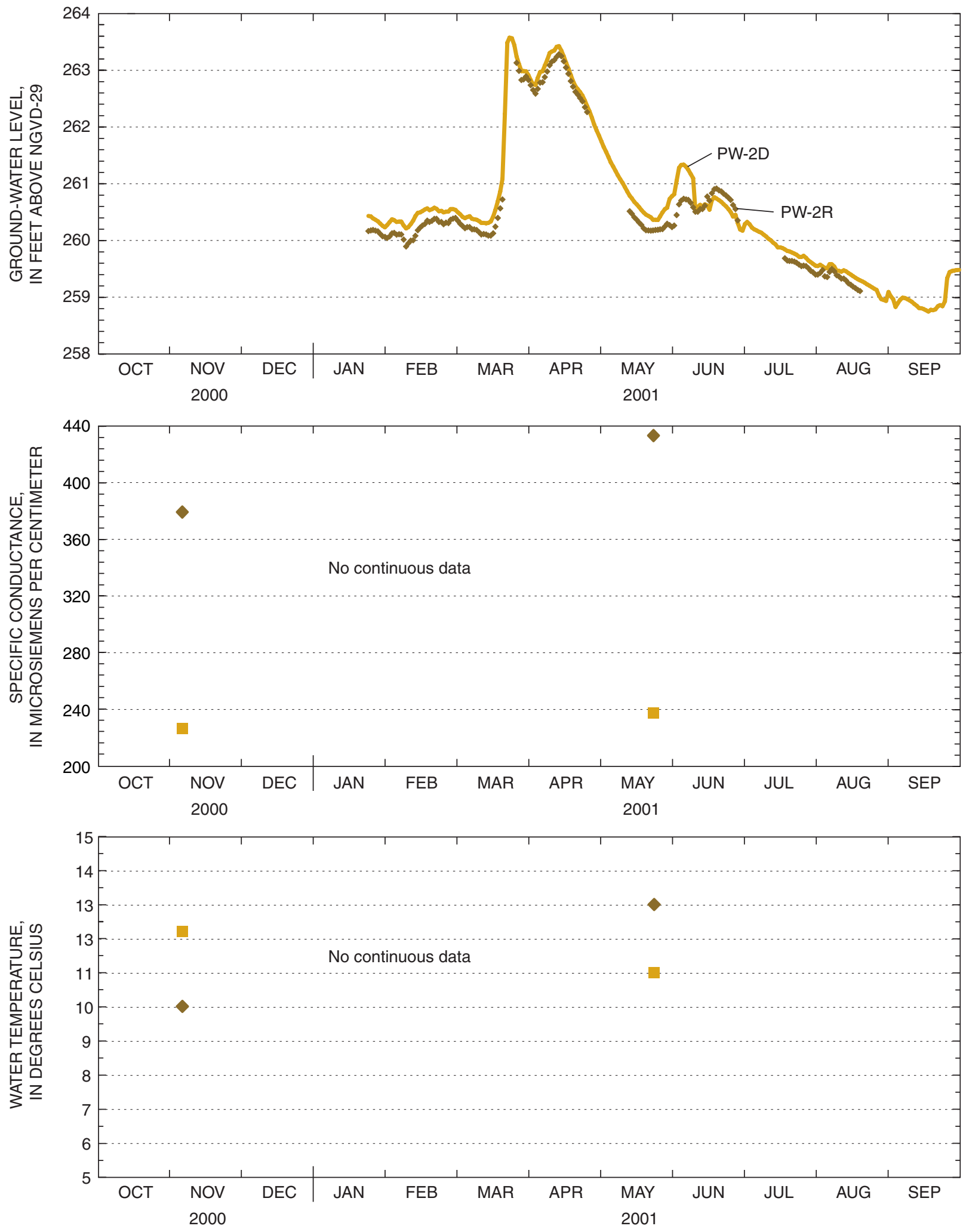

Figure 19. Ground-water levels and physical water properties from monitoring wells PW-2R and PW-2D, water year 2001, Milford, N.H. (Location of wells shown on figure 2. Gaps indicate missing data.) 

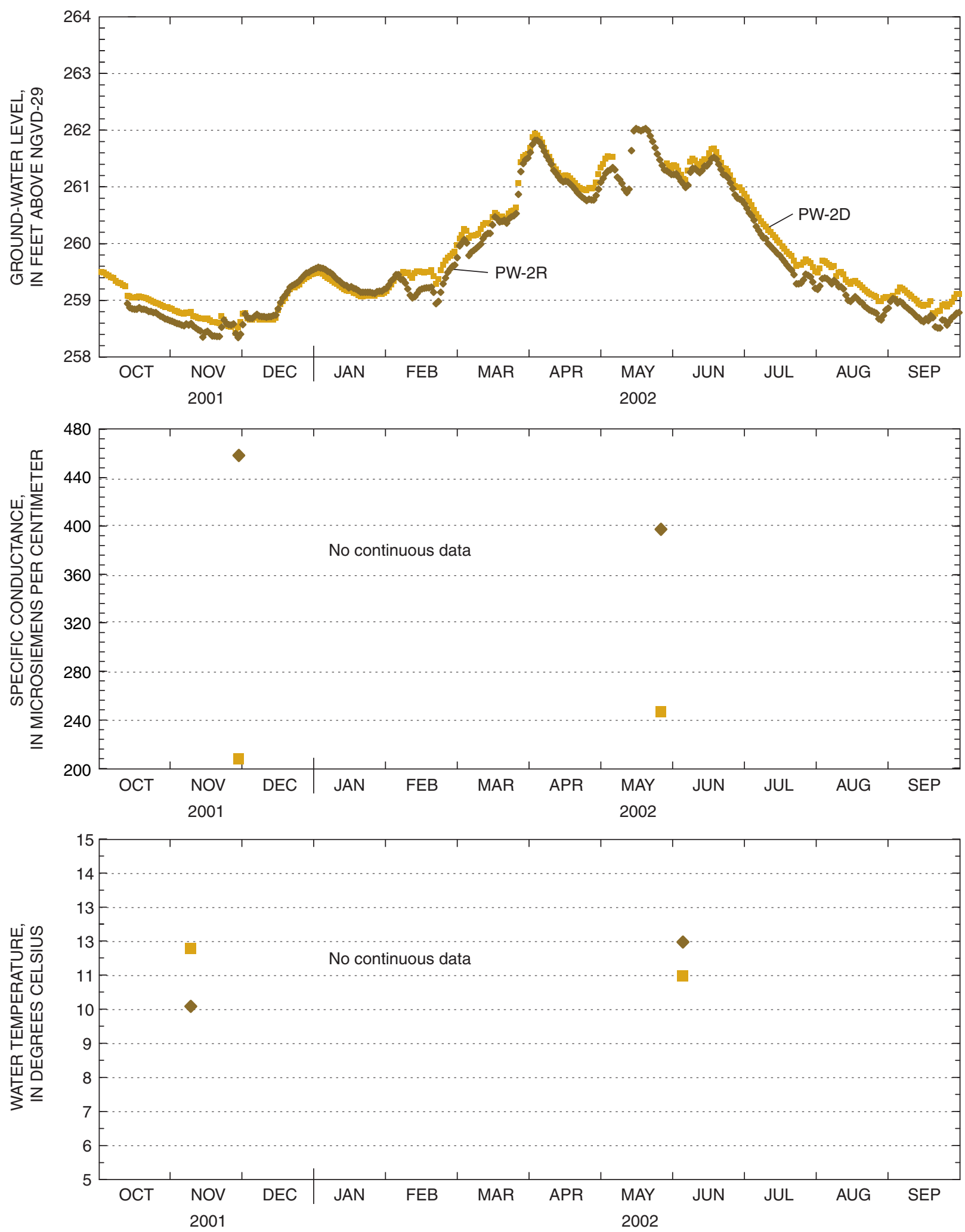

Figure 20. Ground-water levels and physical water properties from monitoring wells PW-2R and PW-2D, water year 2002, Milford, N.H. (Location of wells shown on figure 2. Gaps indicate missing data.) 

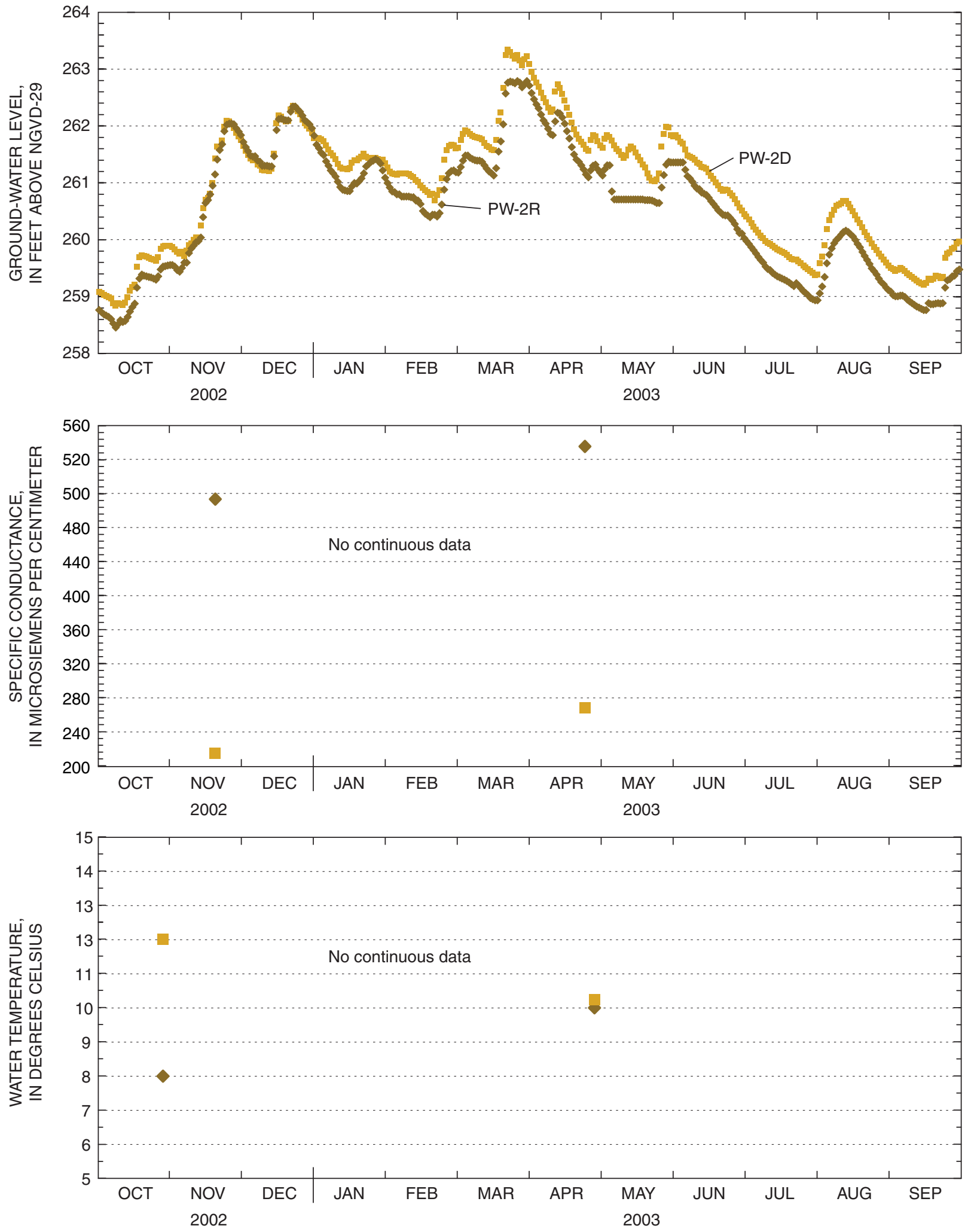

Figure 21. Ground-water levels and physical water properties from monitoring wells PW-2R and PW-2D, water year 2003, Milford, N.H. (Location of wells shown on figure 2. Gaps indicate missing data.) 

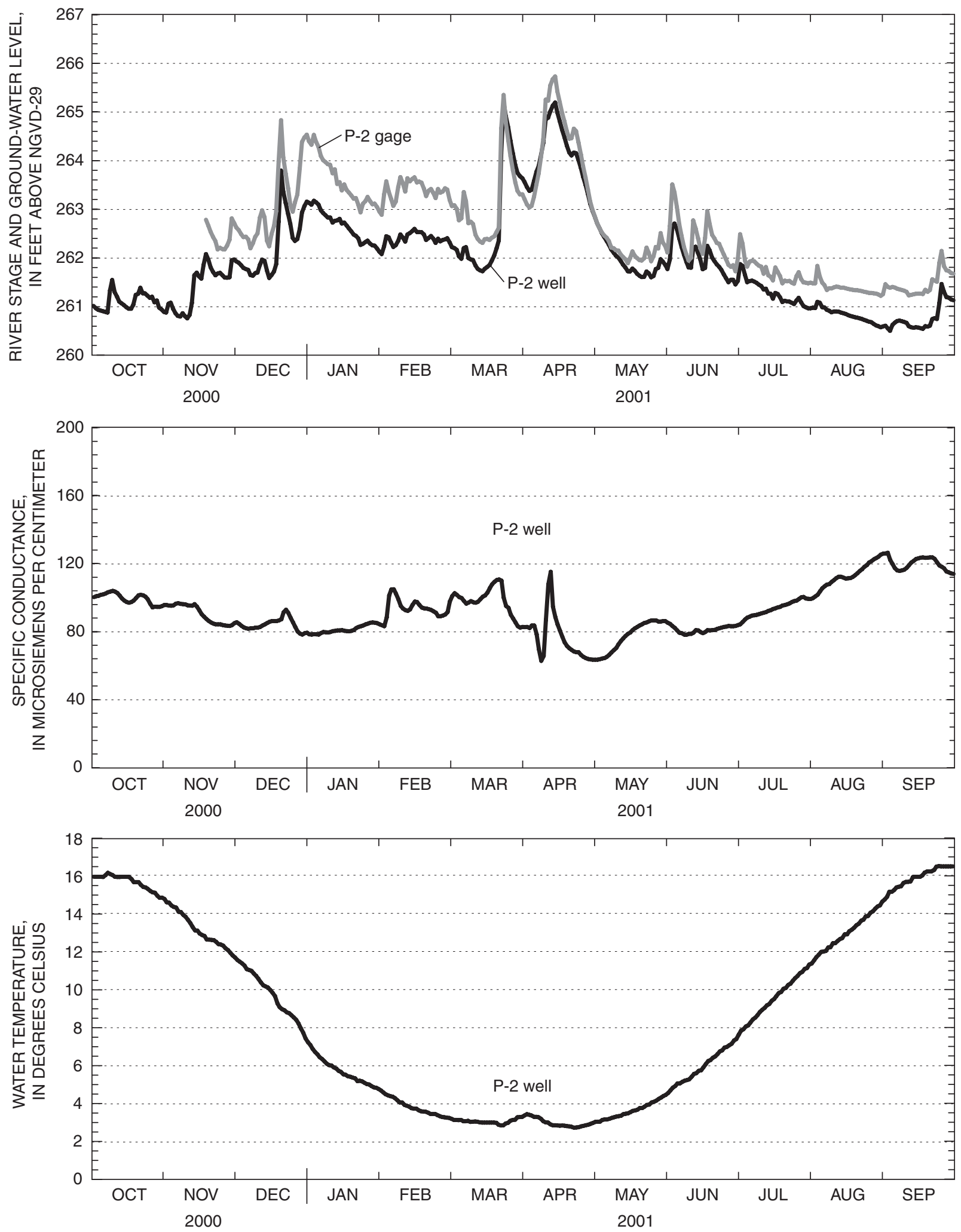

Figure 22. River stage, ground-water levels, and physical water properties from monitoring well P-2 and stream-gaging station P-2, water year 2001, Milford, N.H. (Location of well and station gage shown on figure 2B. Gaps indicate missing data.) 

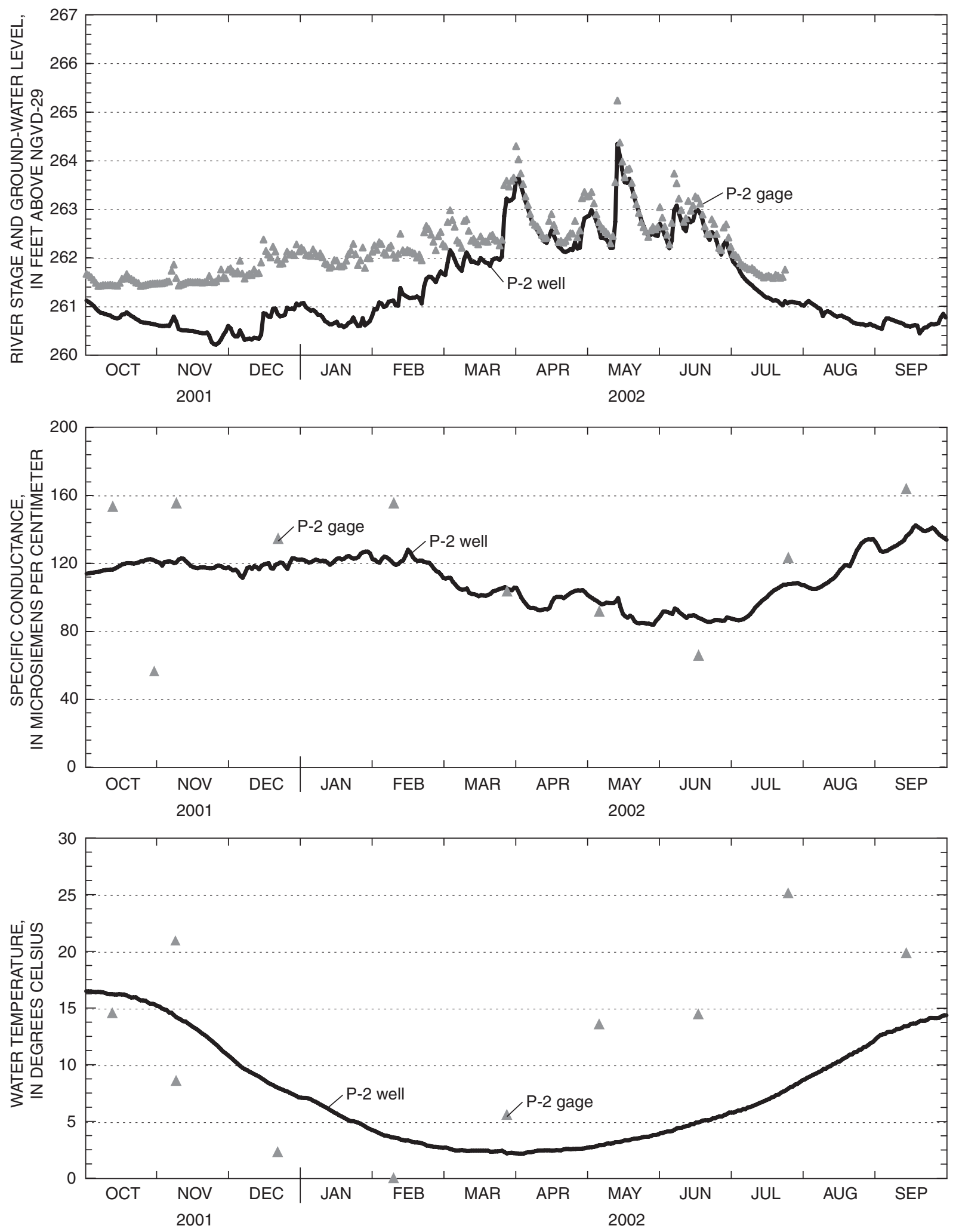

Figure 23. River stage, ground-water levels, and physical water properties from monitoring well P-2 and streamgaging station P-2, water year 2002, Milford, N.H. (Location of well and station gage shown on figure 2B. Gaps indicate missing data.) 

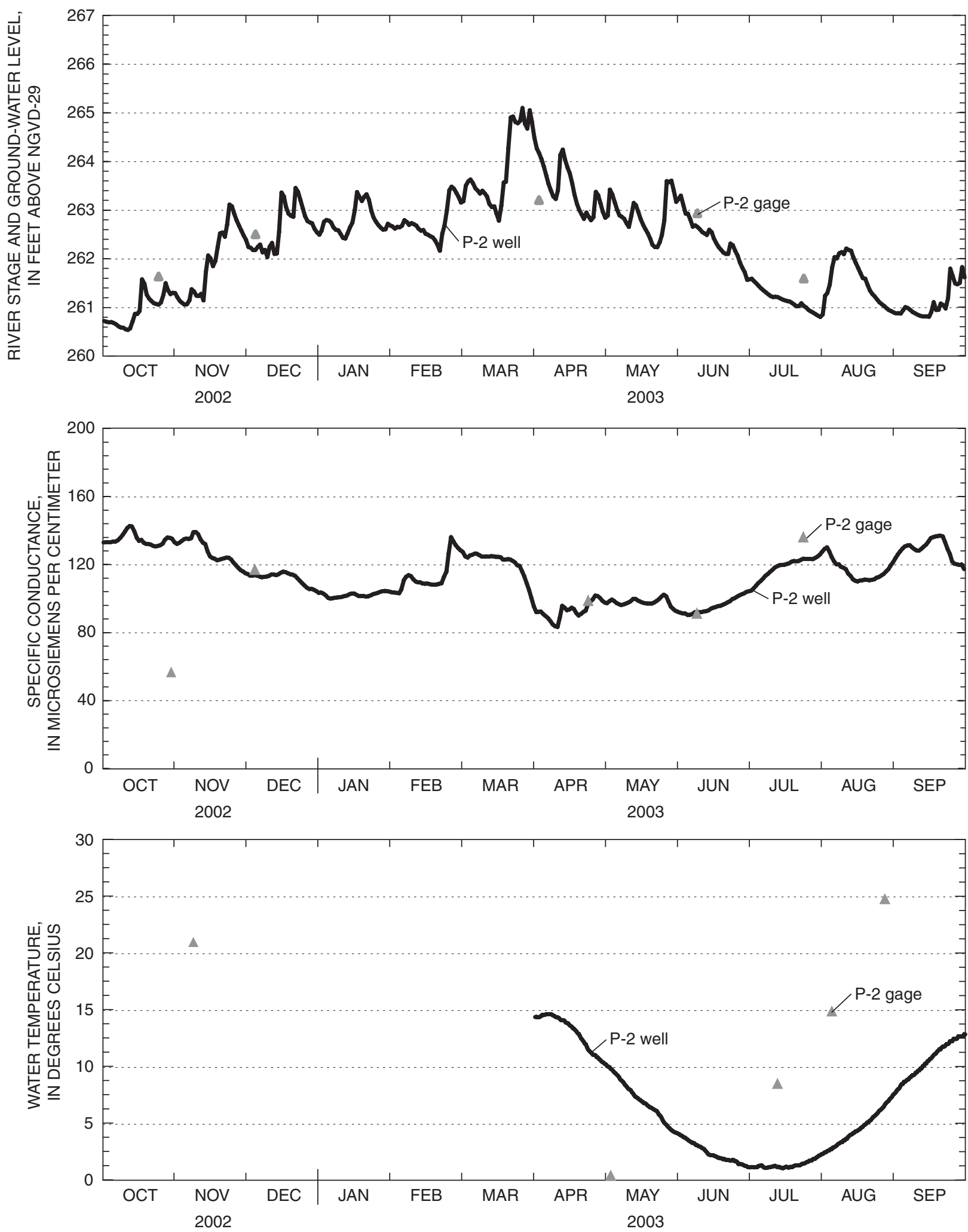

Figure 24. River stage, ground-water levels, and physical water properties from monitoring well P-2 and stream-gaging station P-2, water year 2003, Milford, N.H. (Location of well and station gage shown on figure 2B. Gaps indicate missing data.) 


\section{Summary}

This report summarizes hydrologic and other physical water properties collected in the Operable Unit 1 (OU1) area of the Savage Municipal Well Superfund Site from October 1, 1999, to September 30, 2003 (water years 2000-03). Data collected included river stage, ground-water levels, and physical water properties (specific conductance and water temperature). These data were collected by the U.S. Geological Survey, in cooperation with the New Hampshire Department of Environmental Services and the U.S. Environmental Protection Agency, Region 1, to help assess the effectiveness of remedial operations to mitigate a volatile organic compound (VOC) plume in the OU1 area of the Savage Municipal Well Superfund site, Milford, N.H. The Milford-Souhegan glacial-drift (MSGD) aquifer includes the entire sequence of unsaturated and saturated alluvium, glacial drift, and other unconsolidated deposits. Saturated aquifer thickness ranges from 0 to $100 \mathrm{ft}$ in OU1. The monitoring network of the OU1 area was designed to measure hydraulic responses and to access hydraulic connections across a low-permeability barrier and between the overburden and underlying bedrock from remedial operations.

The VOC plume occurs primarily within the MSGD aquifer but also occurs in the underlying bedrock. The OU1 remedial system contains a semi-circular low-permeability barrier set in the overburden (MSGD aquifer) and a series of extraction and injection overburden wells to contain and capture the VOC plume. Water levels inside and outside the barrier wall respond differently to remedial operations. Water levels respond to either extraction or injection at the following wells, in order of descending response: B95-9, PW-8M, PW5D, PW-5R, PW-2R, and PW-2D. All of these wells are inside the barrier except PW-2R and PW-2D, which are outside the barrier. PW-2R is a bedrock well and shows a greater water-level decrease from extraction at interior withdrawal wells than PW-2D (screened primarily in the lowermost overburden). Water levels in background well MI-18 (in OU2 area) show no response to remedial operation at OU1. Water levels in wells PW-9M and P-2 (both in OU1 but outside the barrier) also show little response to remedial operations. Remedial extraction inside the barrier decreases water levels by about $3 \mathrm{ft}$ as measured between minimum recorded water levels when the extraction system is on and off. Remedial extraction outside the barrier causes negligible drawdown at monitoring wells outside the barrier (PW-2R and PW-2D).

\section{References}

Brayton, M.J., and Harte, P.T., 2001, Results of a monitoring program of continuous water levels, specific conductance, and water temperature at the OK Tool facility of the Savage Municipal Well Superfund site, Milford, New Hampshire: U.S. Geological Survey Open-File Report 01-338, 50 p.
Camp, Dresser, and McKee, Inc., 1995, Final report of vertical contaminant profiling, Savage Municipal Supply Well, Superfund site-OU1, Milford, New Hampshire: Boston, Mass., Federal Programs Corporation, November 1995, 5 chaps., 5 apps.

Camp, Dresser, and McKee, Inc., 1996, Conceptual remedial design report, volume 1, for OK Tool source area, Savage Municipal Supply Well, Superfund site-OU1, Milford, New Hampshire: Cambridge, Mass., March 1996, 5 chaps.

Coakley, M.F., Keirstead, Chandlee, Brown, R.O., and Hilgendorf, G.S., 1997, Water resources data New Hampshire and Vermont water year 1996: U.S. Geological Survey WaterData Report NH-VT-96-1, 189 p.

Harte, P.T., 2004, Simulation of solute transport of tetracholoroethylene in ground water of the glacial-drift aquifer of the Savage Municipal Well Superfund site, Milford, New Hampshire, 1960-2000: U.S. Geological Survey Scientific Investigations Report 2004-5176, 84 p.

Harte, P.T., Brayton, M.J., Ives, Wayne, Perkins, Sharon, and Brown, Carroll, 2001, Testing and application of waterdiffusion samplers to identify temporal trends in volatileorganic compounds: U.S. Geological Survey Open-File Report 00-196, 91 p.

Harte, P.T., Flynn, R.J., and Mack, T.J., 1999, Construction and calibration of numerical ground-water flow models of the Milford-Souhegan glacial-drift aquifer, Milford, New Hampshire: U.S. Geological Survey Open-File Report 99462, 76 p.

Harte, P.T., Flynn, R.H., Kiah, R.G., Severance, Timothy, and Coakley, M.F., 1997, Information on hydrologic and physical properties of water to assess transient hydrology of the Milford-Souhegan glacial-drift aquifer, Milford, New Hampshire: U.S. Geological Survey Open-File Report $97-$ 414, 96 p.

Harte, P.T., and Mack, T.J., 1992, Geohydrology of, and simulation of ground-water flow in, the Milford-Souhegan glacial-drift aquifer, Milford, New Hampshire: U.S. Geological Survey Water-Resources Investigations Report 91-4177, 90 p.

HMM Associates, Inc., 1989, Draft remedial investigation, Savage Well site, Milford, New Hampshire: Concord, Mass., no. 2176 HAZ/2880, 218 p.

HMM Associates, Inc., 1991, Remedial investigation, Savage Well site, Milford, New Hampshire: Concord, Mass., no. 2176 HAZ/4814, 800 p.

National Oceanic and Atmospheric Administration, 2005, National Hurricane Center data for Hurricane Gabrielle, accessed August 23, 2005 , http://www.nhc.noaa.gov/2001.html 
New Hampshire Water Supply and Pollution Control Division, 1985, Hydrogeological investigations of the Savage Well site, Milford, New Hampshire: New Hampshire Water Supply and Pollution Control Commission Report 145, v. 1 and 2 , variously paginated.

U.S. Environmental Protection Agency, 1986, RCRA Technical enforcement guidance document: Washington, D.C., U.S. Environmental Protection Agency Report OSWER9950.1, variously paginated.

U.S. Filter Engineering and Construction, Inc., 2004, Annual evaluation of the groundwater remediation progress at the Savage Municipal Water Supply Superfund site, OU1, The OK Tool Site, July 2002 through June 2003; College Park, Pa., variously paginated. 
Appendixes 1-6 


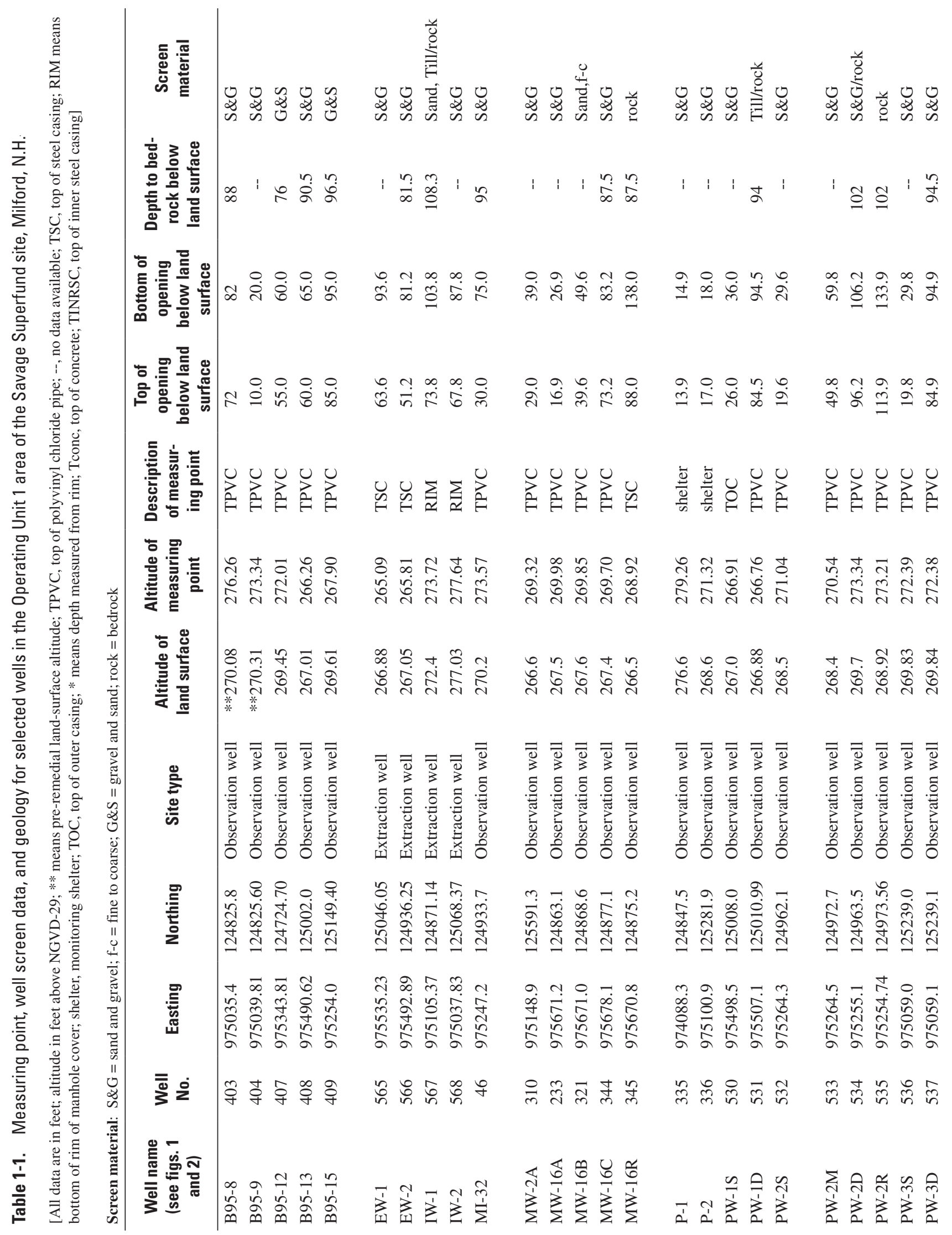




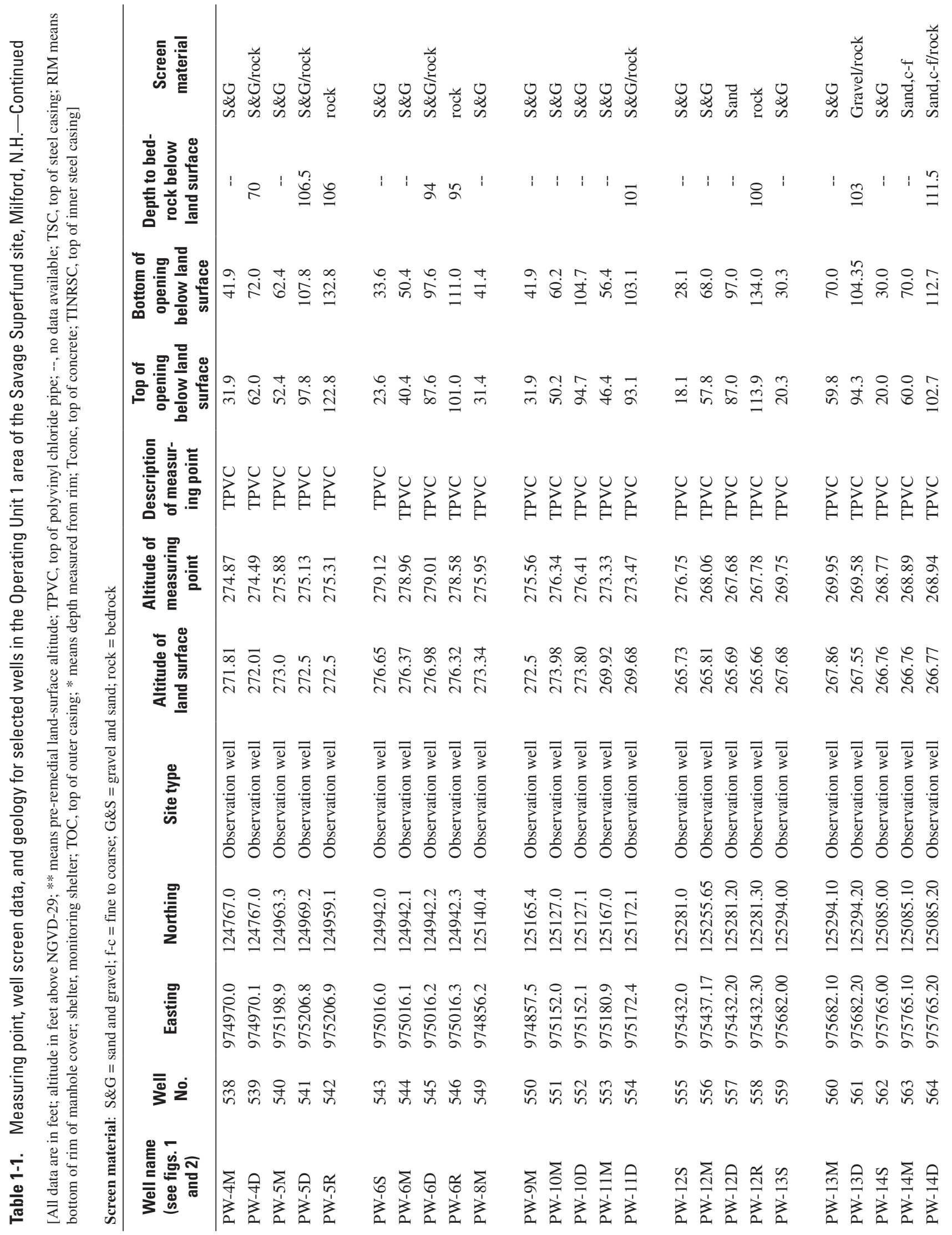




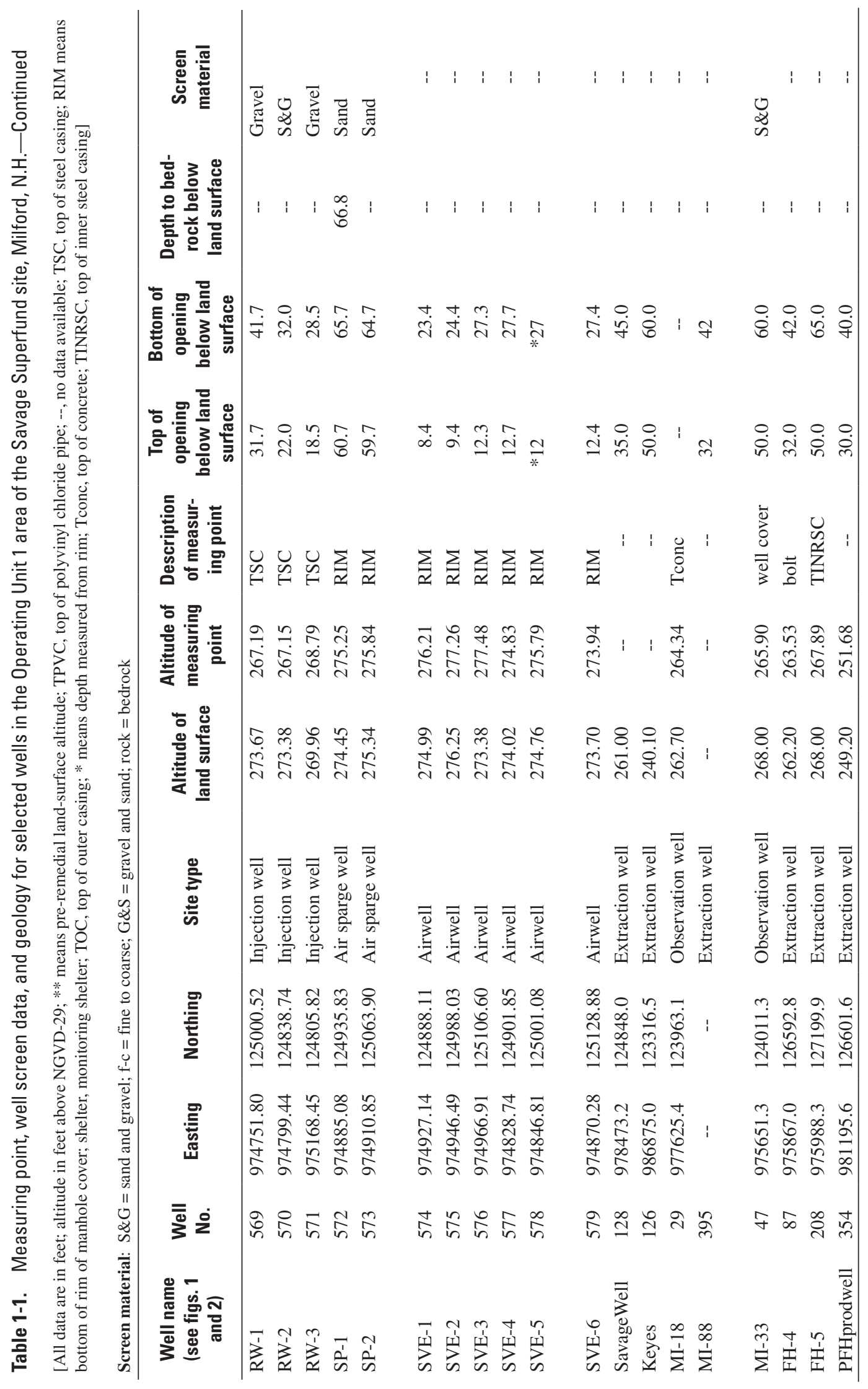


Table 2-1. Summary statistics for water level, specific conductance, and water temperature for automated monitoring wells, water years 2000-03, Milford, N.H.

[--, no data; inc, incomplete record, water levels are in feet above NGVD-29; specific conductance is measured in microsiemens per centimeter at 25 degress Celsius; water temperature is measured in degrees Celsius; MAX, maximum; MIN, minimum; MED, median; Location of wells shown in figures 1 and 2B. Annual precipitation data source from NOAA, National Oceanic Atmospheric Administration]

\begin{tabular}{|c|c|c|c|c|c|c|c|c|c|c|}
\hline \multirow[b]{2}{*}{ Well name } & \multicolumn{4}{|c|}{ Water level } & \multicolumn{3}{|c|}{ Specific conductance } & \multicolumn{3}{|c|}{ Water temperature } \\
\hline & 2000 & 2001 & 2002 & 2003 & 2001 & 2002 & 2003 & 2001 & 2002 & 2003 \\
\hline \multicolumn{11}{|l|}{ B95-9 } \\
\hline MAX & 263.76 & 263.61 & 261.95 & 263.67 & 336.00 & 357.80 & 470.90 & 13.65 & 12.86 & 13.11 \\
\hline MIN & 259.16 & 257.42 & 257.92 & 257.01 & 217.50 & 206.70 & 224.30 & 8.26 & 12.48 & 12.63 \\
\hline MEAN & 261.25 & 260.28 & 259.83 & 259.56 & 262.06 & 281.64 & 301.52 & 11.30 & 11.38 & 11.34 \\
\hline MED & 261.36 & 260.10 & 259.86 & 259.29 & 256.30 & 276.10 & 272.55 & 11.68 & 11.78 & 11.43 \\
\hline \multicolumn{11}{|l|}{ P-2 } \\
\hline MAX & 264.78 & 265.19 & 264.34 & 265.10 & 126.50 & 142.70 & 142.30 & 16.51 & 16.49 & 14.61 \\
\hline MIN & 261.06 & 260.49 & 260.22 & 260.54 & 63.11 & 84.00 & 83.10 & 2.73 & 2.11 & 1.03 \\
\hline MEAN & 262.47 & 261.94 & 261.41 & 262.29 & 92.59 & 111.31 & 113.08 & 8.52 & 7.56 & 6.47 \\
\hline MED & 262.40 & 261.79 & 261.05 & 262.47 & 90.50 & 116.00 & 113.00 & 7.42 & 6.38 & 5.72 \\
\hline \multicolumn{11}{|l|}{ PW-2R } \\
\hline MAX & -- & inc & 262.02 & 262.78 & -- & -- & -- & -- & -- & -- \\
\hline MIN & -- & inc & 258.33 & 258.45 & -- & -- & -- & -- & -- & -- \\
\hline MEAN & -- & inc & 259.75 & 260.56 & -- & -- & -- & -- & -- & -- \\
\hline MED & -- & inc & 259.35 & 260.70 & -- & -- & -- & -- & -- & -- \\
\hline \multicolumn{11}{|l|}{ PW-2D } \\
\hline MAX & -- & inc & 261.93 & 263.33 & -- & -- & -- & -- & -- & -- \\
\hline MIN & -- & inc & 258.41 & 258.84 & -- & -- & -- & -- & -- & -- \\
\hline MEAN & -- & inc & 259.76 & 260.92 & -- & -- & -- & -- & -- & -- \\
\hline MED & -- & inc & 259.42 & 261.16 & -- & -- & -- & -- & -- & -- \\
\hline \multicolumn{11}{|l|}{ PW-5R } \\
\hline MAX & -- & inc & 261.80 & 262.46 & -- & -- & -- & -- & -- & -- \\
\hline MIN & -- & inc & 258.20 & 258.03 & -- & -- & -- & -- & -- & -- \\
\hline MEAN & -- & inc & 259.69 & 260.68 & -- & -- & -- & -- & -- & -- \\
\hline MED & -- & inc & 259.41 & 260.75 & -- & -- & -- & -- & -- & -- \\
\hline \multicolumn{11}{|l|}{ PW-5D } \\
\hline MAX & -- & inc & 261.41 & 262.89 & -- & -- & -- & -- & -- & -- \\
\hline MIN & -- & inc & 257.44 & 257.15 & -- & -- & -- & -- & -- & -- \\
\hline MEAN & -- & inc & 259.29 & 259.39 & -- & -- & -- & -- & -- & -- \\
\hline MED & -- & inc & 259.23 & 259.29 & -- & -- & -- & -- & -- & -- \\
\hline \multicolumn{11}{|l|}{ PW-8M } \\
\hline MAX & -- & inc & 261.65 & 263.23 & inc & 190.00 & 266.90 & inc & -- & -- \\
\hline MIN & -- & inc & 261.65 & 263.23 & inc & 140.00 & 172.30 & inc & -- & -- \\
\hline MEAN & -- & inc & 259.50 & 259.64 & inc & 159.74 & 215.25 & inc & -- & -- \\
\hline MED & -- & inc & 259.51 & 259.49 & inc & 161.50 & 213.60 & inc & -- & -- \\
\hline \multicolumn{11}{|l|}{ PW-9M } \\
\hline MAX & -- & inc & 265.63 & 265.90 & inc & 501.70 & 303.80 & inc & 14.46 & 15.01 \\
\hline MIN & -- & inc & 265.63 & 265.90 & inc & 141.60 & 170.20 & inc & 7.35 & 6.17 \\
\hline MEAN & -- & inc & 262.87 & 263.43 & inc & 217.02 & 220.89 & inc & 10.79 & 10.49 \\
\hline MED & -- & inc & 262.72 & 263.56 & inc & 178.10 & 220.60 & inc & 10.72 & 10.49 \\
\hline \multicolumn{11}{|l|}{ MI-18 } \\
\hline MAX & 257.37 & 258.13 & 257.07 & 257.35 & -- & -- & -- & -- & -- & -- \\
\hline MIN & 255.19 & 254.04 & 254.18 & 254.45 & -- & -- & -- & -- & -- & -- \\
\hline MEAN & 255.94 & 255.64 & 255.43 & 255.99 & -- & -- & -- & -- & -- & -- \\
\hline MED & 255.89 & 255.69 & 255.32 & 256.08 & -- & -- & -- & -- & -- & -- \\
\hline $\begin{array}{c}\text { Annual } \\
\text { precipitation, } \\
\text { in inches }\end{array}$ & 41.22 & 40.05 & 34.88 & 46.91 & & & & & & \\
\hline
\end{tabular}


A.

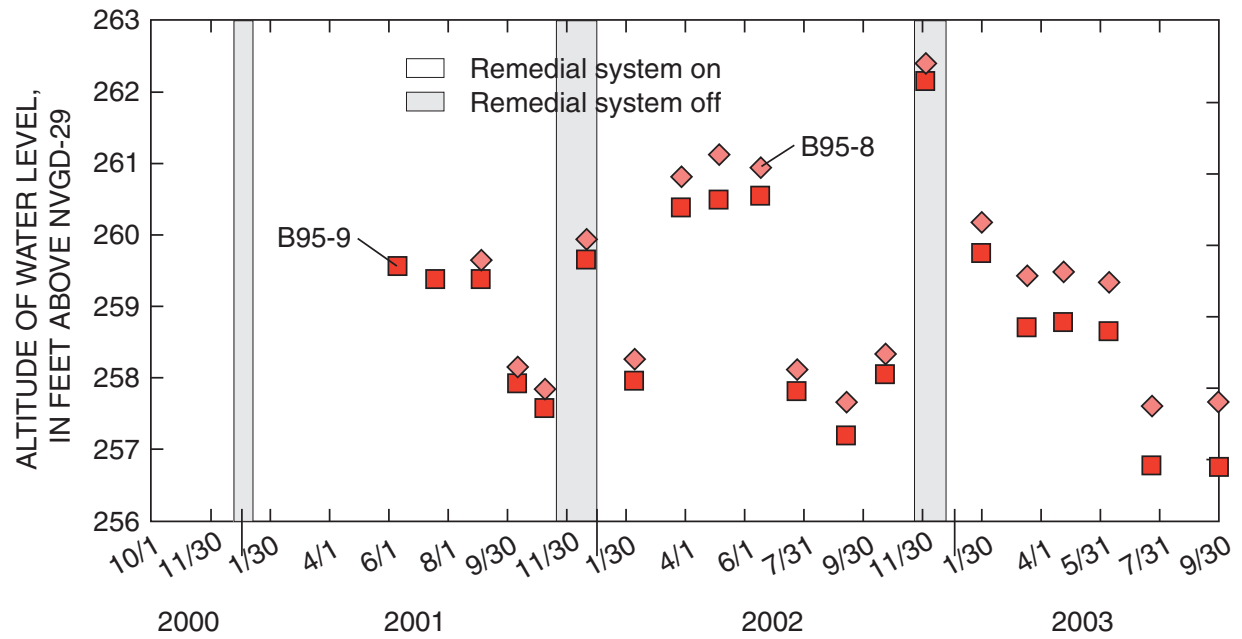

B.

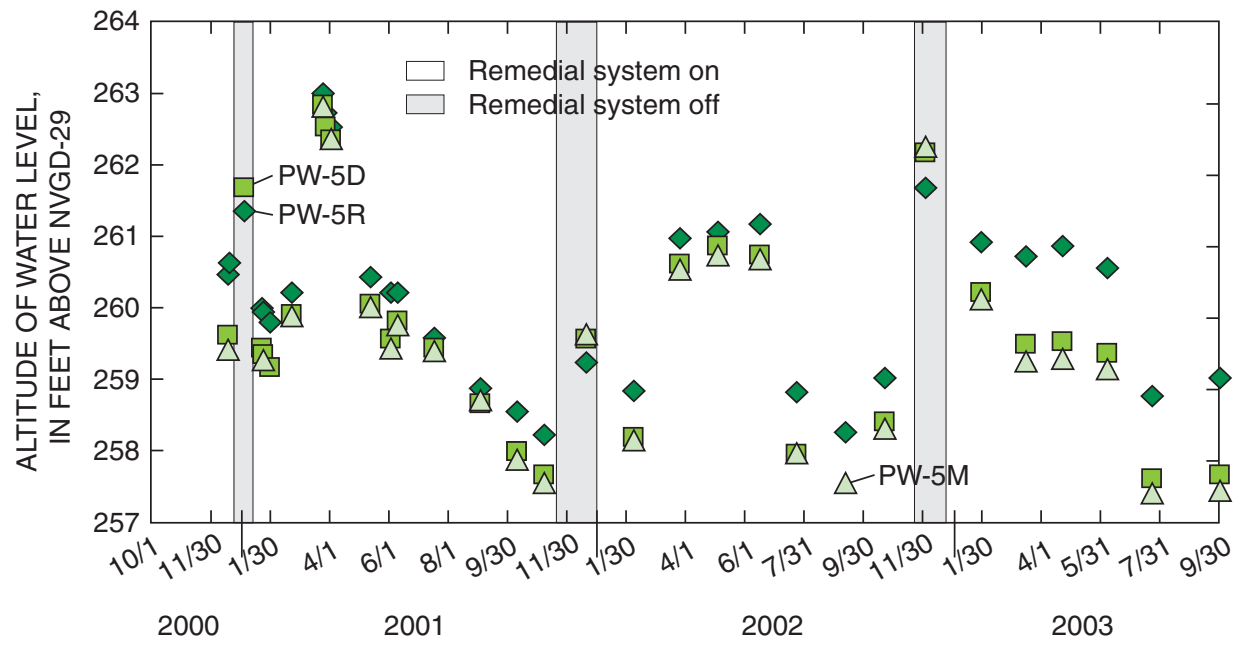

c.

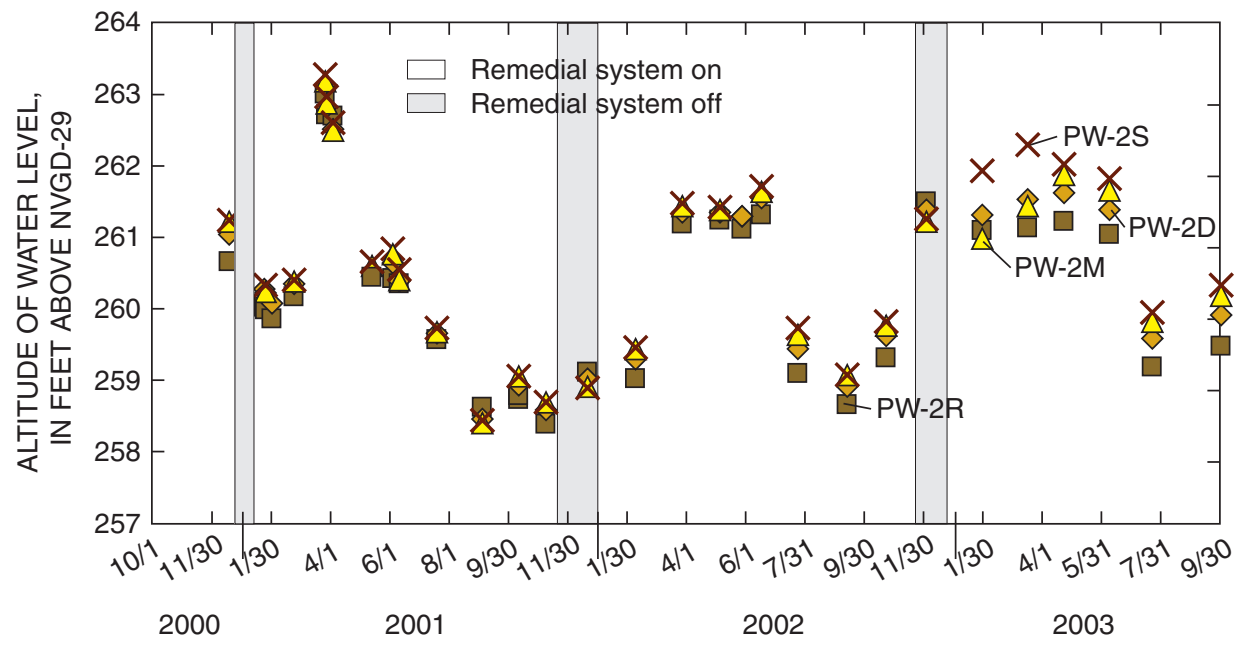

Figure 3-1. Periodic manual measurements of water levels for selected wells, water years 2000-03, Milford, N.H. (A) monitoring wells B95-8 and B95-9; (B) cluster monitoring wells PW-5R, PW-5D, and PW-5M inside the barrier wall; and (C) cluster monitoring wells PW-2D, PW-2R, PW-2M, and PW-2S outside the barrier wall. 


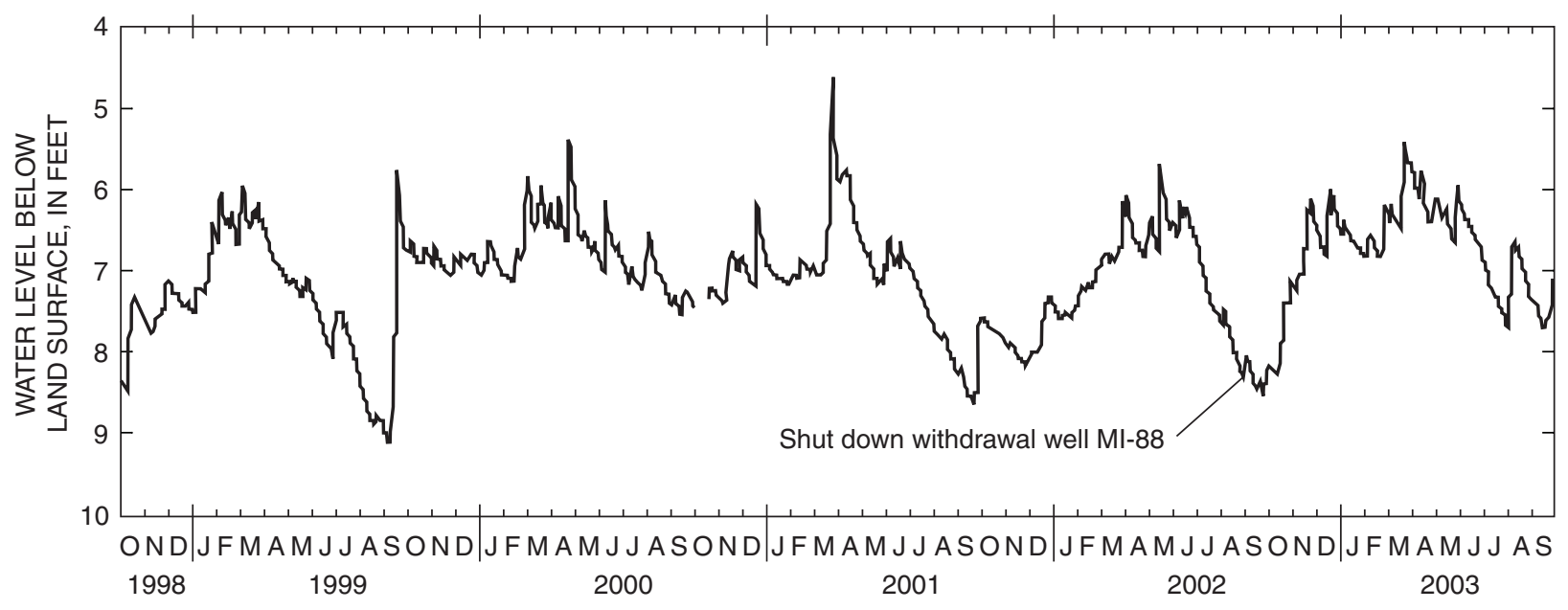

Figure 4-1. Continuous (daily average) water levels for well MI-18, water years 1998-2003, Operable Unit 2 (OU2) area of the Savage Superfund site, Milford, N.H.

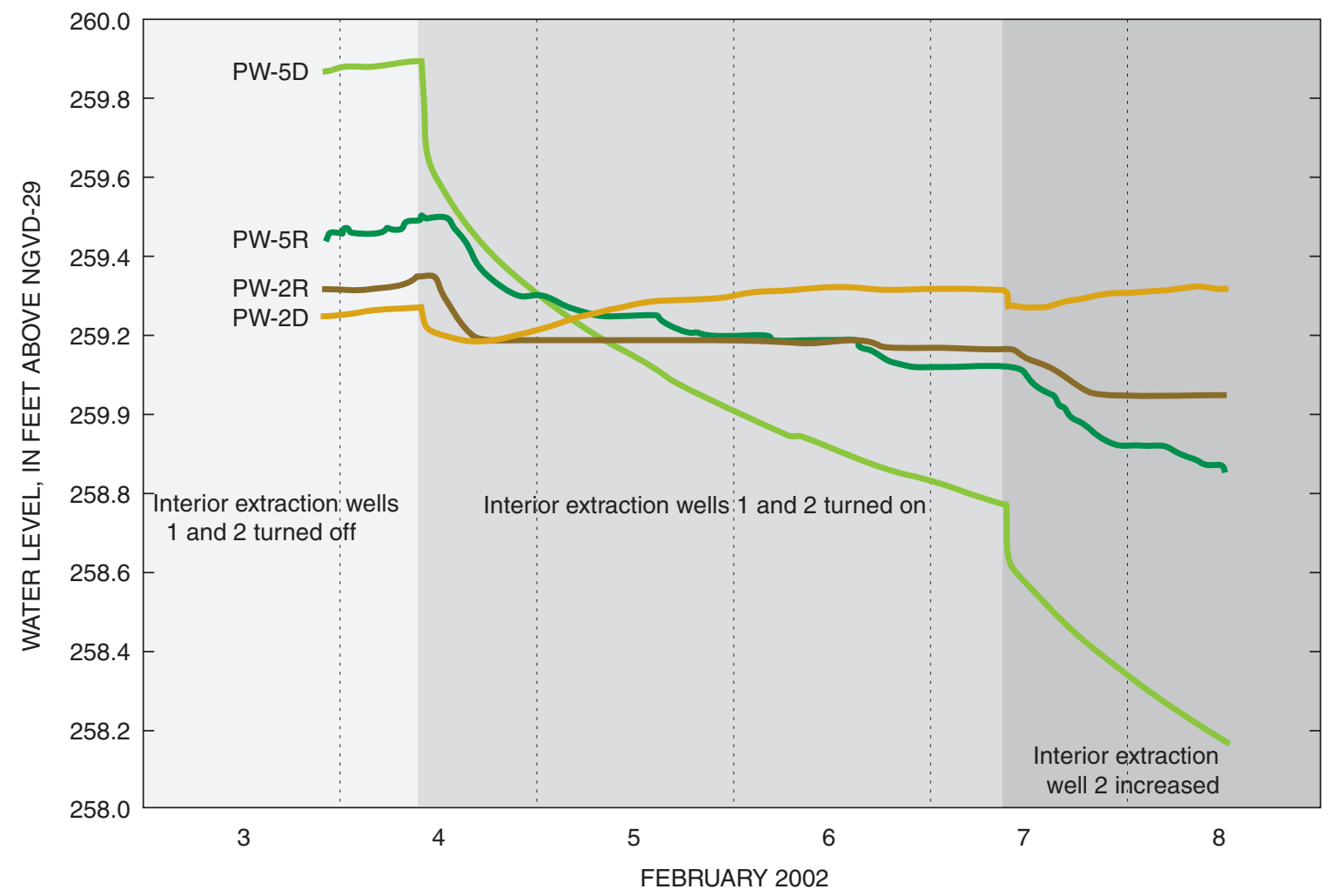

Figure 5-1. Continuous (15-minute) water levels for wells PW-5R and PW-5D (inside barrier) and PW-2R and PW-2D (outside barrier), February 2002, Operable Unit 1 (OU1) area of the Savage Superfund site, Milford, N.H. 


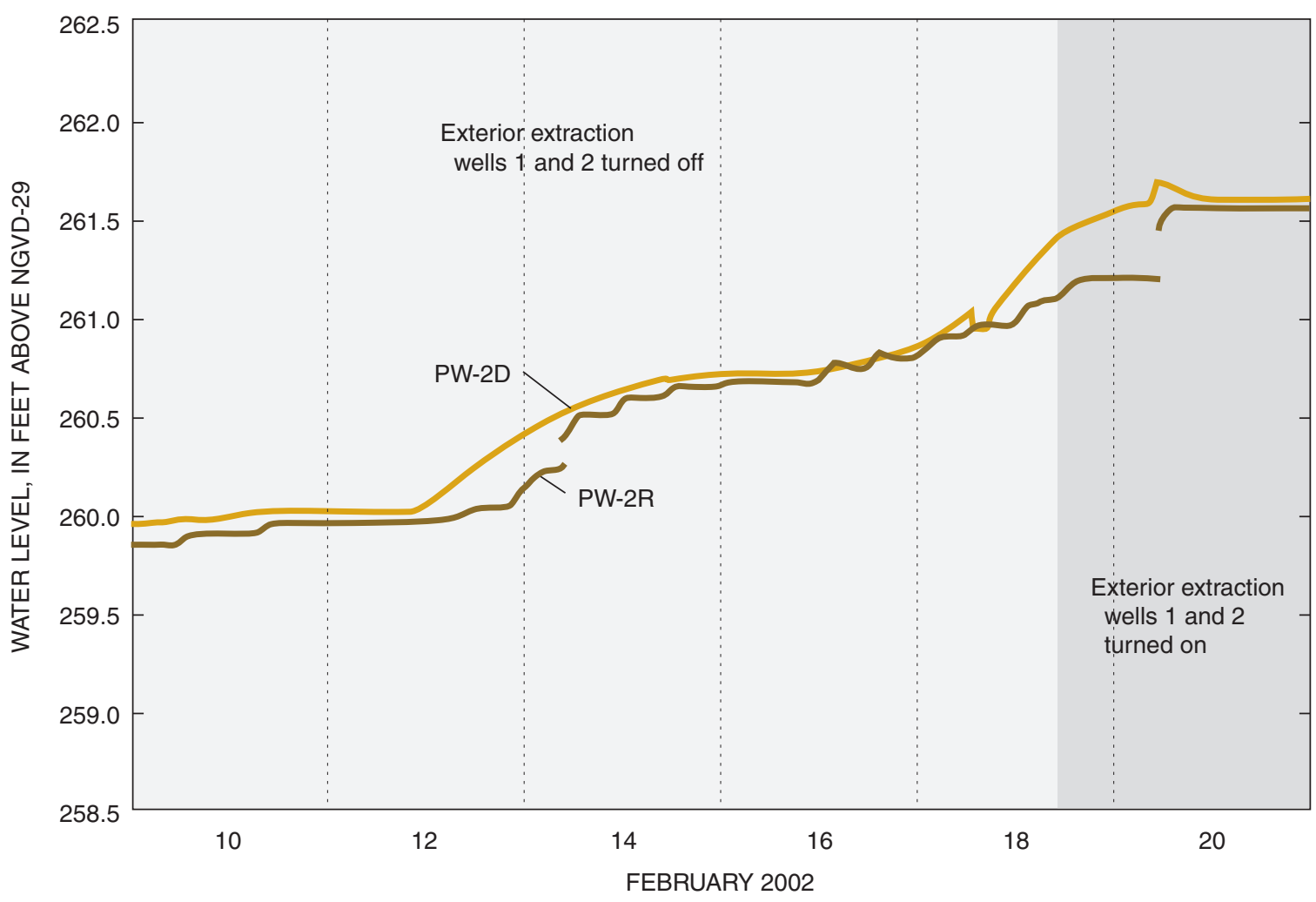

Figure 6-1. Continuous (15-minute) water levels for wells PW-2R and PW-2D (outside barrier), November 2002, Operable Unit 1 (OU1) area of the Savage Superfund site, Milford, N.H. Gaps indicate missing data. 
Prepared by the New Hampshire-Vermont Water Science Center Publications Unit

For more information concerning the research in this report, contact:

Brian R. Mrazik, Director

U.S. Geological Survey

New Hampshire-Vermont Water Science Center

361 Commerce Way

Pembroke, NH 03275

or visit our Web site at:

http://nh.water.usgs.gov 